\title{
Cranial anatomy of Bolotridon frerensis, an enigmatic cynodont from the Middle Triassic of South Africa, and its phylogenetic significance
}

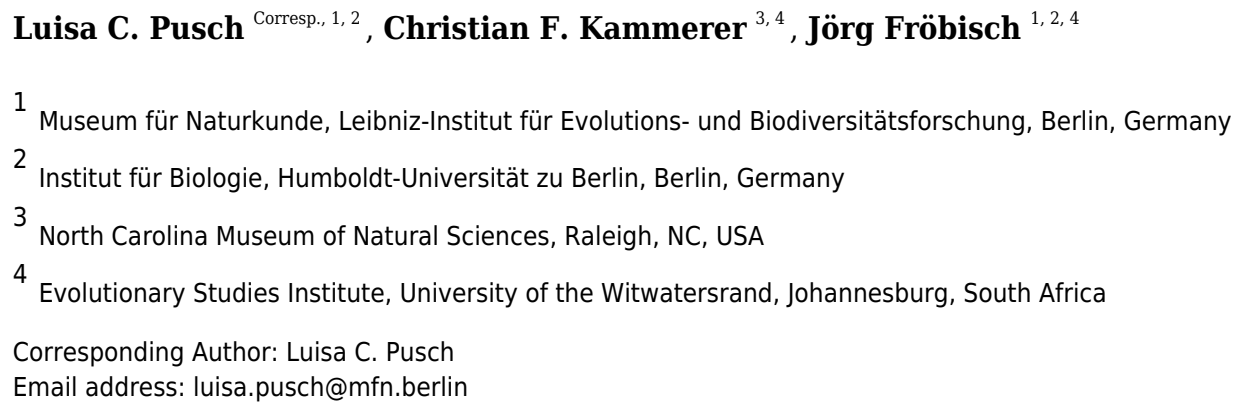

The cynodont fauna of the Trirachodon-Kannemeyeria Subzone of the Middle Triassic Cynognathus Assemblage Zone (AZ) is almost exclusively represented by taxa belonging to the clade Eucynodontia. However, there is one basal (non-eucynodont) cynodont known to have survived into this assemblage: the enigmatic Bolotridon frerensis. BSPG 1934-VIII-7 represents by far the most extensive specimen of $B$. frerensis, consisting of a partial skull with occluded lower jaw. The specimen was initially described by Broili \& Schröder (1934), but their description was limited to surface details of the skull and the dental morphology. Here, by using a computed tomographic (CT) reconstruction, we redescribe this specimen, providing novel information on its palatal and internal anatomy. New endocranial characters recognized for this taxon include ridges in the nasal cavity indicating the presence of cartilaginous respiratory turbinals. New data obtained from the CT scan were incorporated into the most recently published data matrix of early non-mammalian cynodonts to test the previously unstable phylogenetic position of Bolotridon. Our phylogenetic analyses recovered Bolotridon as the sister-taxon of Eucynodontia, a more crownward position than previously hypothesized. 
1 Cranial anatomy of Bolotridon frerensis, an enigmatic

2 cynodont from the Middle Triassic of South Africa, and

3 its phylogenetic significance.

4

5

6 Luisa C. Pusch ${ }^{1,2}$, Christian F. Kammerer ${ }^{3,4}$, Jörg Fröbisch ${ }^{1,2,4}$

7

$8{ }^{1}$ Museum für Naturkunde, Leibniz-Institut für Evolutions- und Biodiversitätsforschung, Berlin,

9 Germany

10 2Institut für Biologie, Humboldt-Universität zu Berlin, Berlin, Germany

$11{ }^{3}$ North Carolina Museum of Natural Sciences, Raleigh, NC, USA

${ }^{4}$ Evolutionary Studies Institute, University of the Witwatersrand, Johannesburg, South Africa

Corresponding Author:

Luisa C. Pusch ${ }^{1,2}$

Invalidenstraße 43, Berlin, 10115, Germany

17 Email address: luisa.pusch@mfn.berlin 


\section{Abstract}

23

24 The cynodont fauna of the Trirachodon-Kannemeyeria Subzone of the Middle Triassic

25 Cynognathus Assemblage Zone (AZ) is almost exclusively represented by taxa belonging to the

clade Eucynodontia. However, there is one basal (non-eucynodont) cynodont known to have survived into this assemblage: the enigmatic Bolotridon frerensis. BSPG 1934-VIII-7 represents by far the most extensive specimen of B. frerensis, consisting of a partial skull with occluded lower jaw. The specimen was initially described by Broili \& Schröder (1934), but their description was limited to surface details of the skull and the dental morphology. Here, by using a computed tomographic (CT) reconstruction, we redescribe this specimen, providing novel information on its palatal and internal anatomy. New endocranial characters recognized for this taxon include ridges in the nasal cavity indicating the presence of cartilaginous respiratory turbinals. New data obtained from the CT scan were incorporated into the most recently published data matrix of early non-mammalian cynodonts to test the previously unstable phylogenetic position of Bolotridon. Our phylogenetic analyses recovered Bolotridon as the sister-taxon of Eucynodontia, a more crownward position than previously hypothesized.

\section{Introduction}

Cynodontia is one of the six major therapsid subclades and was the last to diversify, first appearing in the fossil record in the late Permian but not showing substantial species richness until the Middle Triassic, when it became the most diverse and abundant synapsid group (Hopson \& Kitching, 1972; Kemp, 2005; Abdala \& Ribeiro, 2010; Angielczyk \& Kammerer, 2018; Lukic-Walther et al., 2019). In the form of their mammalian descendants, cynodonts remained the most successful synapsid lineage throughout the Mesozoic and onwards to the 
48 present day. By contrast, early in their history cynodonts are a minor component of terrestrial 49 ecosystems, and with a few notable exceptions (e.g., Galesaurus, Thrinaxodon) are rare and

50 poorly known from late Permian and earliest Triassic faunas. However, recent work has 51 improved our knowledge of early cynodont diversity. Abdala et al. (2019) described a new, 52 surprisingly large cynodont taxon (Vetusodon elikhulu) from the late Permian (Lopingian) of the 53 Karoo Basin in South Africa, and Huttenlocker \& Sidor (2020) described another new taxon 54 (Nshimbodon muchingaensis) from the upper Permian Madumabisa Mudstone Formation of 55 Zambia. In addition to Vetusodon, five further Permian cynodont taxa are currently recognized 56 from the Karoo Basin: Charassognathus gracilis and Abdalodon diastematicus (the oldest 57 known cynodonts, currently known from a single skull each from the upper Endothiodon 58 Assemblage Zone [AZ]), Procynosuchus (a broadly-distributed taxon with additional records 59 from elsewhere in Africa and in Europe), and Cynosaurus suppostus and Nanictosaurus 60 kitchingi. The latter two genera may represent early representatives of primarily Triassic 61 lineages, suggesting that the cynodont radiation had begun prior to the end-Permian mass 62 extinction (Broom, 1937; Kemp, 1979; Van Heerden \& Rubidge, 1990; Abdala \& Allison, 2005; 63 Botha, Abdala \& Smith, 2007; Kammerer, 2016; Van den Brandt \& Abdala, 2018; Abdala et al., 64 2019; Viglietti et al. 2020).

65 None of the late Permian genera are known to have survived the end-Permian mass 66 extinction, but at least two lineages (Galesauridae and Thrinaxodontidae) seem to have crossed 67 the Permo-Triassic boundary, and were fairly abundant in the Lower Triassic Lystrosaurus 68 declivis AZ of the Karoo Basin in South Africa (Botha \& Smith, 2020). Galesaurids are 69 represented in the Triassic by the taxa Galesaurus and Progalesaurus (e.g., Sidor \& Smith, 2004; 70 Pusch, Kammerer \& Fröbisch, 2019), whereas Thrinaxodontidae is represented by the extremely 
71 common and extensively studied taxon Thrinaxodon (e.g., Fourie, 1974; Rowe, Carlson \&

72 Bottorff, 1995; Abdala, Jasinoski \& Fernandez, 2013; Jasinoski, Abdala \& Fernandez, 2015). A

73 rarer representative of early cynodonts in the Lystrosaurus declivis AZ is the unusually broad-

74 skulled genus Platycraniellus (Abdala, 2007). By the Middle Triassic, these taxa had

75 disappeared, with later Triassic cynodonts consisting almost exclusively of members of the

76 diverse clade Eucynodontia. At least seven genera of eucynodonts are recorded in the Middle

77 Triassic Cynognathus AZ (and additional, undescribed taxa are also probably present; see

78 Hendrickx et al. 2020): the cynognathians Cynognathus, Diademodon, Langbergia, Cricodon,

79 Trirachodon, the probainognathian Lumkuia, and the phylogenetically uncertain taxon

80 Cistecynodon (Brink \& Kitching, 1953; Hopson \& Kitching, 2001; Abdala \& Giannini, 2002;

81 Sidor \& Smith, 2004; Abdala, Hancox \& Neveling, 2005; Abdala \& Ribeiro, 2010). Most of

82 these genera (all but Langbergia and Cricodon) are known from the most extensively-exposed

83 and best-studied portion of the Cynognathus AZ, the Trirachodon-Kannemeyeria Subzone

84 (Hancox, Neveling \& Rubidge, 2020).

85 One additional cynodont taxon is currently recognized from the Trirachodon-Kannemeyeria

86 Subzone, the enigmatic Bolotridon frerensis. Preliminary studies have suggested that Bolotridon

87 (=Tribolodon; see Coad, 1977) is the only basal (i.e., non-eucynodont) cynodont to survive into

88 the Middle Triassic (Sidor \& Smith, 2004; Abdala, Hancox \& Neveling, 2005; Abdala \&

89 Ribeiro, 2010). However, the rarity and incompleteness of the known material of this taxon have

90 made it difficult to resolve its phylogenetic position, which has been tested computationally in

91 only one analysis (Sidor \& Smith, 2004). Hopson \& Kitching (1972) regarded Bolotridon as a

92 member of the family Galesauridae, albeit in a pre-cladistic sense containing all non-eucynodont

93 epicynodonts, rather than an indication of any particular relationship to Galesaurus. Battail 
94 (1991) included Bolotridon in the family Thrinaxodontidae based on the possible presence of a 95 complete osseous palate. However, the presence of a complete secondary palate has never been

confirmed for Bolotridon. The earliest definite presence of this mammal-like feature in

cynodonts occurs in thrinaxodontids, and this character is then retained in all crownward taxa (Fourie, 1974; Van Heerden \& Rubidge, 1990; Hopson, 1991; Crompton, Musinsky \&

Owerkowicz, 2015; Crompton et al., 2017). An exception to its universal retention has recently been suggested for the Permian Vetusodon, which has an incomplete secondary palate, but was recovered crownward of Thrinaxodon in the initial analysis of Abdala et al. (2019). However, the most recent phylogeny by Huttenlocker \& Sidor (2020) supports a more basal position for Vetusodon, placing it with Cynosaurus near the base of Epicynodontia (outside of the origin of the complete secondary palate).

The holotype of Bolotridon frerensis is a partial left dentary (NHMUK PV R2583), which was described by Seeley $(1894,1895)$ and collected at the historic Cynognathus AZ locality of Lady Frere Commonage (Cacadu, Chris Hani District Municipality, Eastern Cape Province) in South Africa. A right femur and left tibia (NHMUK PV R2584) were found together with the holotype while removing matrix from a skull of "Gomphognathus" (=Diademodon) (Seeley, 1895 ) and have been referred to $B$. frerensis as well, but the association of these elements with the holotype jaw is questionable. The majority of other referred specimens from the type locality also only represent isolated dentary or maxillary elements (BSPG 1934-VIII-8, 9, 501, 502, 503, 504, and 505) and do not provide further information on the broader anatomy of this taxon. The sole exception to this is the specimen BSPG 1934-VIII-7, which is by far the most complete known specimen of $B$. frerensis and consists of a partial skull with occluded lower jaw (Fig. 13). Broili \& Schröder (1934) provided an initial description of BSPG 1934-VIII-7, but their 
117 description was limited to surface details and focused on the dental morphology of this and other

118 referred specimens. The tight occlusion of the upper and lower jaws also prevented the authors

119 from exposing the palatal region without damaging the skull through overpreparation.

120 Accordingly, the morphology of the palate remains largely unknown.

121 Here, we present a redescription of Bolotridon frerensis based on computed tomographic

122 (CT) reconstruction of BSPG 1934-VIII-7. This provides new insights into the previously-

123 obscured palatal region and novel information on endocranial characters in this taxon. Although

124 the palate is damaged in BSPG 1934-VIII-7, our redescription provides substantial new data on

125 its anatomy allowing incorporation into the most recent published data matrix of basal cynodonts

126 (Huttenlocker \& Sidor, 2020). This new information is used to test the currently unstable

127 phylogenetic placement of Bolotridon (Hopson \& Kitching, 1972; Battail, 1991; Sidor \& Smith,

128 2004). We also discuss the faunal composition of the Cynognathus AZ, with special focus on

129 Lady Frere Commonage, which yields seemingly unusual faunal elements not recorded in other 130 exposures of this assemblage zone.

131

132 Materials \& Methods

133

134 Specimen

135 The specimen of Bolotridon frerensis described herein (BSPG 1934-VIII-7; Fig. 1-9) is part of

136 the collection of the Bayerische Staatssammlung für Paläontologie und Geologie in Munich. The

137 block containing the fossil remains of this and most other referred specimens of B. frerensis

138 (BSPG 1934-VIII-8, 9, 501, 502, 503, 504, and 505) was collected in the Burgersdorp

139 Formation, in exposures representing the Trirachodon-Kannemeyeria Subzone of the Middle

140 Triassic Cynognathus AZ. It was discovered by G. Grossarth at Lady Frere Commonage in 1931, 
141 as part of a research trip by the Bayerische Akademie der Wissenschaften. The specimens were

142 later prepared by the technician G. Kochner of the same institution (Broili \& Schröder, 1934).

143 The skull of BSPG 1934-VIII-7 is laterally compressed and cracked, but the dentition and many

144 of the individual cranial elements are in good condition. The total length of the specimen is 8.1

$145 \mathrm{~cm}$ and its maximum width is $\sim 3.7 \mathrm{~cm}$.

\section{Computed tomography data}

BSPG 1934-VIII-7 was CT scanned in the CT-Laboratory of the Museum für Naturkunde Berlin using an YXLON FF35 X-ray CT scanner with a voxel size of $0.0463 \mathrm{~mm}$, a voltage of $115 \mathrm{kV}$ and a current of $220 \mu \mathrm{A}$. The visualization of the slices, virtual 3D rendering, and segmentation of selected structures were performed using VGStudio Max 3.3 (Volume Graphics GmbH, Heidelberg, Germany) in the 3D Visualization Laboratory at the Museum für Naturkunde Berlin.

\section{Phylogenetic analyses}

BSPG 1934-VIII-7 was coded into the dataset of the most recent phylogenetic analysis of early non-mammalian cynodonts (Huttenlocker \& Sidor, 2020) to assess its relationships. The matrix of Huttenlocker \& Sidor (2020) was largely modified from those of Abdala (2007) and Kammerer (2016) and contains a few newly adapted characters from other sources. We reduced the number of characters in their matrix from 111 to 110 , because one character was present twice (character $27=64$; we deleted the repeated character 64 ). The data matrix further comprises 26 therapsid taxa: two gorgonopsians (Aelurognathus and Cyonosaurus) used as outgroups, eight therocephalians, and 16 cynodonts including the newly added Bolotridon. A 
164 branch lengths of zero set to collapse. For the analysis, a heuristic search with tree-bisection165 reconnection (TBR) branch-swapping was performed, with multistate characters unordered. A 166 bootstrap analysis was conducted based on 1,000 replicates to assess clade support. Additionally, 167 a Bayesian analysis was performed in MrBayes v. 3.2.7 (Ronquist \& Huelsenbeck, 2003) using 168 the Markov model (Lewis, 2001) with a gamma distributed rate parameter. The Markov chain

169 Monte Carlo analysis ran for one million generations (run time 15.11 minutes) until the standard 170 deviation of split frequencies fell below 0.01 . The results of both analyses are included into the 171 updated character list (Supplemental Data 1) and the updated data matrix can be found in 172 Supplemental Data 2 and 3.

173

174

175

176

177 General preservation

178 179 180

\section{Results}

The skull of BSPG 1934-VIII-7 is missing the septomaxillae, temporal region, and occiput. It is laterally compressed, with the right half of the skull having been shifted somewhat posteriorly and ventrally and the left half somewhat anteriorly and dorsally (Fig. 1-3). A small fragment of bone is preserved lateral to the coronoid process of the right dentary and posterior to the jugal, which might pertain to the squamosal (Fig. 1, 2, 4) (this element is otherwise not preserved in this specimen). The palate of BSPG 1934-VIII-7 was strongly affected by lateral compression, and resolution of the palate in the CT-scan is not ideal, but the scan still provides substantial information about the morphology of this region that is not visible externally (Fig. 5, 7). The lower jaw of BSPG 1934-VIII-7 consists of the dentaries, right splenial, anterior portion of the left angular, and prearticulars, with the right prearticular being more complete. The left 
188 preartcular is preserved only as a small fragment. The left splenial, right angular, and both 189 surangulars, coronoids, and articulars are missing in this specimen (Fig. 1-4, 8).

190

191 Snout

192 The premaxilla is a small bone forming the anteriormost margin of the snout and the

193 anteromedial and ventral margins of the external naris. Its prenasal (intranarial) process, which is

194 slightly damaged ventrally, extends dorsally to contact the nasals (Fig. 1-4). The facial portion of

195 the premaxilla is posteriorly overlain by the maxilla up to the level of the fourth incisor (Fig. 2,

196 3). Each premaxilla bears four conical, slightly recurved incisors, which appear unusually long in

197 Bolotridon compared to other basal cynodonts (although their apparent length could be an

198 artifact of slipping out of their sockets post mortem). The left incisor row has been slightly

199 shifted forward, with the result that the left I4 is positioned around the same level as the right I3,

200 and the right I1 and left I1, I2 and I3 are very close together. The fourth incisor on both sides is

201 considerably smaller than the preceding three teeth. The right I4 has partially fallen out of its

202 socket and is displaced posteroventrally. Palatally, the premaxilla forms a broad plate underlying

203 the anterior portion of the vomer. At the posterolateral margin of this plate, the premaxilla is

204 separated from the maxilla by an oval paracanine fossa accommodating the crown of the lower

205 canine. This fossa is positioned anteromedial to the canine, as is usual for basal cynodonts.

206 Lateral to the paracanine fossa, a short diastema is present between I4 and the upper canine (Fig.

$2072,3,4,7 B)$.

208 The dorsal roof of the snout and nasal cavity is formed by elongate nasal bones. The nasals

209 are transversely narrow at their anterior edge, and narrow further (appearing 'pinched' in dorsal

210 view) at mid-length where they are overlapped by the dorsal edges of the maxillae before 
211 broadening posteriorly. The nasals contact the frontals posteriorly and the lacrimals and

212 prefrontals posterolaterally, around the level of the anterior orbital margin (Fig. 1, 2, 3, 6). In

213 internal view, the ventral margin of the nasal bone projects deeply into the nasal cavity and is

214 slightly overlapped by the anterior and dorsal portion of the lacrimal posteriorly (Fig. 4, 5B). The

215 underside of the nasals is generally concave, but becomes flatter in the region where they contact

216 the lacrimals. It is characterized by a series of ridges extending anteriorly from the interorbital

217 region along the ventral surface of the frontals and continuing onto the nasals. These ridges

218 consist of a median ridge along the midline suture, which weakens anteriorly, and a pair of

219 lateral ridges running parallel to the median ridge (Fig. 5B, 6). Similar ridges are known from a

220 number of therapsids and have been interpreted as attachment points for cartilaginous nasal

221 turbinals, with the median ridge possibly supporting the dorsal edge of a cartilaginous nasal

222 septum (e.g., Kemp, 1979; Hillenius, 1994; Sigurdsen, 2006; Crompton, Musinsky \&

223 Owerkowicz, 2015; Crompton et al., 2017; Bendel et al., 2018; Pusch, Kammerer \& Fröbisch,

224 2019; Pusch et al., 2020; Huttenlocker \& Sidor, 2020).

225 The maxilla is a large bone that extends over most of the lateral surface of the snout and

226 forms much of the sidewall of the nasal cavity and the secondary palate (Fig. 1-4, 7). Medially,

227 the two maxillae contact one another on the ventral surface of the snout. Unfortunately, because

228 of strong lateral compression, it is uncertain whether the maxillae naturally contacted one

229 another to form a complete secondary palate. The maxillae are clearly distorted to some degree,

230 as both palatal processes have been shifted against each other, with the right palatal process

231 overlapping the left one (Fig. 7B). A similar case of deformation-induced contact of the medial

232 projections of the maxillae was recently described for the Early Triassic cynodont Galesaurus

233 (Pusch, Kammerer \& Fröbisch, 2019) (undistorted Galesaurus skulls indicate that this taxon did 
234 not have a complete secondary palate). Despite their damage, based on the proportions of the 235 maxillary projections in Bolotridon, the secondary palate of this taxon must have been at least as 236 extensive as in Galesaurus (i.e., more expansive than in Permian cynodonts such as 237 Procynosuchus, Dvinia, Abdalodon and Vetusodon, in which the medial processes are 238 transversely shorter; Tatarinov, 1968; Kemp, 1979; Hopson \& Kitching, 2001; Ivakhnenko, 239 2013; Kammerer, 2016; Abdala et al., 2019).

Both the external and internal surfaces of the maxillae are generally smooth, although the 241 external surfaces of both maxillae are marked by some slight cracks (Fig. 2, 3, 4). The internal 242 surface of the maxilla is dorsally strongly overlapped by the ventral margin of the nasals and 243 anteriorly it is covered by the palatal process of the premaxilla. Posteriorly, it is overlapped by 244 the anterior margins of the lacrimal and jugal, and also by the dorsolateral portions of the 245 damaged and displaced palatine (Fig. 4, 5, 7A). Three large foramina perforate the external 246 surface of the maxilla above the tooth row, marking the openings of rami from the maxillary 247 canal. Unfortunately, we were unable to resolve the course of the maxillary canal in the CT-scan, 248 as it was damaged due to the strong compression of the snout. A total of nine right and eleven left upper postcanines are present in BSPG 1934-VIII-7 (Fig. 2, 3, 7B). The number of upper postcanines slightly differs from what was described by 251 Broili \& Schröder (1934), who originally counted ten postcanines in the left maxilla. The 252 discrepancy is likely due to the tight occlusion of upper and lower jaws, making it difficult to see 253 the actual number of the teeth without CT data. The postcanines increase in size from the first to 254 the penultimate tooth. The last postcanine is noticeably smaller than the penultimate tooth in the 255 left maxilla. On the right side the last postcanine is damaged, but appears comparable in size to 256 its predecessor, suggesting that the small size of the left last postcanine could be a result of its 
257 recent eruption at the time of death. However, several postcanines have damaged crowns, with 258 only the left PC6, PC9, PC10, and PC11 and the right PC5, PC6, and PC8 being completely

259 preserved, showing the tricuspid morphology described by Broili \& Schröder (1934). Notable is 260 the morphology of the intact left PC6 and right PC5 and PC6, which appear to naturally have a 261 shorter main cusp than the more posterior teeth, in which the main cusp is more pronounced. 262 This is most clearly visible in the left PC9, PC10, and PC11 (Fig. 2, 3). The presence of two 263 separated lingual cingular cusps cannot be observed for both upper and lower postcanines in BSPG 1934-VIII-7 due to damage, but have been described in other referred specimens of $B$.

265 266 267 268 269 270 271 272 273 274 275 276 277 278 279

frerensis with better preserved teeth (Broili \& Schröder, 1934). There is a short diastema present between the upper canine and the anteriormost upper postcanine, with the left canine being relatively well preserved, whereas in the right canine the crown is more damaged. Serrations are absent on all teeth, and distinct carinae are not present on the canines (Fig. 2, 3, 7B, 8).

The anterior margin of the orbit is formed by the lacrimal, which contacts the prefrontal dorsally, the nasal anterodorsally, the maxilla anteriorly and the anterior part of the jugal posteroventrally (Fig. 2, 3). The medial surface of the lacrimal is posteriorly overlapped by the anterior and ventral margins of the prefrontal. Anteriorly, it covers part of the posterior portion of the maxilla. Its medial surface contacts the palatine, although the extent of this contact has been exaggerated due to compression (Fig. 5B). On the floor of the orbit, the posteroventral extension of the lacrimal also contacts the pterygoid and covers the anterior part of the jugal. The lacrimal is perforated posteriorly by two small foramina, through which the nasolacrimal canal originates in the anterior edge of the orbit. The canal runs anteriorly through a ridge on the medial surface of the lacrimal and opens at the level of the sixth lower postcanine above a small maxillary antrum, which was only weakly visible in the scan (Fig. 4, 5). A short ridge appears to 
280 extend slightly forward beyond this opening (Fig. 4). In the 3D reconstruction it resembles the 281 structure described for Galesaurus (Pusch, Kammerer \& Fröbisch, 2019) and Thrinaxodon

282 (Crompton, 2013). However, we cannot exclude the possibility that this is just a crack caused by 283 damage and compression of the maxilla in that area. Clear evidence of ridges extending forward 284 beyond the opening of the lacrimal canal have so far been provided for only a few non285 mammalian cynodonts, with their earliest appearance in Galesaurus and Thrinaxodon, and have 286 been interpreted as forming the base for cartilaginous maxilloturbinals (Fourie, 1974; Hillenius, 287 1994; Crompton, 2013; Crompton, Musinsky \& Owerkowicz, 2015; Crompton et al. 2017; 288 Pusch, Kammerer \& Fröbisch, 2019).

289 The prefrontal contributes to the anterodorsal edge and also partly to the medial wall of the 290 orbit. Its anterodorsal portion contacts the nasal anteriorly and the lacrimal ventrally, and its 291 posterodorsal portion contacts the postorbital posteriorly (Fig. 1, 2, 3, 6). The suture between the 292 prefrontal and nasal is relatively short in BSPG 1934-VIII-7, related to the small size and slender 293 shape of the prefrontal. The contact between the nasal and lacrimal is accordingly somewhat 294 longer than what is usually observed in basal cynodonts, in which the prefrontal tends to be a 295 larger bone occupying more of this region (e.g., Fourie, 1974; Kemp, 1979; Sidor \& Smith, 296 2004; Abdala, 2007; Botha, Abdala \& Smith, 2007; Kammerer, 2016; Van den Brandt \& Abdala, 297 2018; Abdala et al., 2019; Pusch, Kammerer \& Fröbisch, 2019). The dorsal margin of the 298 prefrontal is curved and projects inwards to overlap the anterolateral process of the lateral flange 299 of the frontal. In internal view, its anterior margin also slightly overlies the lacrimal along its 300 posterior and posteroventral margins (Fig. 1-4, 5A, 6).

301 The incomplete jugals make up the posterolateral floor of the orbit and the ventral portion 302 of the zygomatic arch. They contact the maxilla anteriorly, the lacrimal anterodorsally and the 
303 anterolateral portion of the pterygoid medially. The better preserved left jugal also slightly

304 contacts the posterolateral tip of the palatine. A contact of the jugal with the palatine seems to be

305 naturally present, as has also been described for Galesaurus (Pusch, Kammerer \& Fröbisch,

306 2019). The missing contact between these bones on the right side is likely an artifact of

307 deformation caused by shifting of the skull halves. In internal view, the jugal is anteriorly

308 overlapped by the posteroventral margin of the lacrimal, which is in turn overlapped by the

309 prefrontal. The jugal forms the ventral portion of the postorbital bar, in the form of a dorsally-

310 directed 'spike' that would have contacted the postorbital bone (preserved on the left side only).

311 The posterior preserved tip of the right jugal contacts the fragmented piece of bone that might

312 belong to the squamosal (Fig. 1-4, 7).

313

314 Skull roof

315 The frontals are anteroposteriorly elongate bones extending between the nasals anteriorly and the

316 parietals (of which only a fragment is preserved that does not provide much information on the

317 morphology of the bone) posteriorly. Anterolaterally, the frontal's lateral flange is overlapped by

318 the curved dorsal margin of the prefrontal, and posterolaterally it contacts the dorsal part of the

319 postorbital (Fig. 1-4, 5A). A deep, elongate depression on the ventral surface of the frontals,

320 which is divided by a faint median ridge into left and right compartments, marks the location for

321 the olfactory bulbs of the brain. The lateral and partial anterior limit of the olfactory bulbs is

322 bounded by two ridges, which weaken anteriorly until they meet a pronounced ridge at the

323 midline suture of the frontals marking the hindmost part of the nasal cavity (Fig. 4, 5A, 6).

324 Similar ridges bounding the olfactory bulbs have been described for the basal cynodonts

325 Procynosuchus (Kemp, 1979) and Galesaurus (Pusch, Kammerer \& Fröbisch, 2019), as well as 
326 the probainognathian Chiniquodon (Kemp, 2009). The posterior limit of the olfactory bulbs is

327 likely indicated by the gradual transition from slight concavity to convexity of the ventral surface

328 of the frontals at the level of the postorbital bar (Fig. 4, 6). The pronounced ridge originating at

329 the midline suture of the frontals just anterior to the depression housing the olfactory bulbs of the

330 brain also marks the posterior limit of the cartilaginous nasal septum, which was likely attached

331 to the median ridge (Crompton, Musinsky \& Owerkowicz, 2015; Crompton et al. 2017).

332 The postorbitals are badly damaged, with only their anterior portion being preserved. The

333 postorbital contributes to the dorsal margin of the orbit by contacting the posterior portion of the

334 prefrontal anterodorsally and the posterior portion of the frontals dorsolaterally. It also would

335 have formed the posterodorsal portion of the postorbital bar, though its descending ramus

336 contacting the jugal is not preserved (Fig. 1, 2, 3, 6).

337

338 Palate

339 The morphology of the strongly compressed and displaced unpaired vomer is difficult to resolve

340 in the scan of BSPG 1934-VIII-7. It is an elongated strip of bone dividing the nasopharyngeal

341 passage at the midline, which appears to be very narrow as a result of lateral compression of the

342 skull halves (Fig. 5, 7). The anterior portion of the vomer, which overlies the palatal process of

343 the premaxilla (Fig. 7A), is usually characterized by having a grooved dorsal surface housing the

344 vomeronasal organ in therapsids (e.g., Hillenius, 2000; Crompton et al., 2017; Kammerer, 2017,

345 Bendel et al., 2018; Pusch, Kammerer \& Fröbisch, 2019; Pusch et al., 2020). However, in BSPG

346 1934-VIII-7 the anterior portion of the vomer is clearly damaged, and the housing for the

347 vomeronasal organ is not evident (Fig. 7A). The posterior portion of the vomer has two lateral

348 'wings', which are not in their natural positions, with the left wing also being bent ventrally due 
349 to damage. These wings are wedged posteriorly between the medially directed plates of the 350 palatines, together forming a transverse lamina, which forms the posterior border of the long 351 primary choanae that extend the length of the vomer and open into the nasopharyngeal passage 352 (Fig. 5, 7A), as has also been described for Galesaurus (Pusch, Kammerer \& Fröbisch, 2019), 353 Thrinaxodon (Crompton, 2013) and the more crownward eucynodonts Massetognathus and 354 Probainognathus (Crompton, Musinsky \& Owerkowicz, 2015; Crompton et al., 2017). As has 355 been suggested by Hillenius (1994), Crompton et al. (2017), and Pusch, Kammerer \& Fröbisch 356 (2019), it is likely that the space dorsal to the transverse lamina made up an olfactory chamber, 357 and the large space anterior to the transverse lamina provided a respiratory chamber, which was 358 presumably filled with cartilaginous maxilloturbinals attached to the short ridge running forward 359 beyond the opening of the lacrimal canal (Fig. 4, 5).

360 The palatines are laterally compressed, resulting in a strong dorsal displacement especially 361 for the left palatine, which almost reaches the nasals (Fig. 5B, 7). Anteriorly, the palatine 362 contacts the maxilla on the secondary palate. Although damaged, the palatine forms much of the 363 floor, lateral wall and roof of the nasopharyngeal passage and part of the posterolateral wall of 364 the olfactory chamber (Fig. 5, 7) (Crompton et al., 2017; Pusch, Kammerer \& Fröbisch, 2019). 365 Similar to Galesaurus (Pusch, Kammerer \& Fröbisch, 2019), the dorsal surface of the palate 366 posterior to the internal choanae consists almost solely of the palatines, with components of the 367 lacrimal laterally, the jugal posterolaterally and the pterygoid posteriorly and posteromedially 368 (Fig. 5, 7).

369 As in the case of the vomer and palatines, the preserved portions of the pterygoids are 370 laterally compressed, with the left pterygoid having been stretched as a result of anterior shifting 371 of the left half of the skull, and the right pterygoid having been strongly compressed due to 
372 posterior shifting of the right half of the skull. The pterygoid forms the posterior portion of the

373 palate, contacting the narrow posterior end of the vomer and the palatines anteriorly, and the

374 posteroventral extension of the lacrimal and the anterior portion of the jugal anterolaterally. It

375 bears a short transverse flange, which descends far down the medial surface of the dentary, with

376 its ventral tip contacting the anterior portion of the prearticular. An ectopterygoid, which is

377 usually situated at the lateral margin of the transverse flange of the pterygoid, could not be 378 clearly delimited in the scan, but based on the condition in other basal cynodonts is likely to be

379 present (Fig. 4, 7). Despite incompleteness of the posterior portions of the pterygoids, no

380 interpterygoid vacuity seems to be present between them (Fig. 7), potentially indicating maturity 381 in this specimen.

382

383 Lower jaw

384 The lower jaw of BSPG 1934-VIII-7 is tightly occluded to the upper jaw, and has suffered 385 compression comparable to that of the cranium. Anteriorly, the left and right dentaries seem to be fused at the symphysis (Fig. 2, 3, 4, 8, 9). A fused mandibular symphysis, which is typically considered a eucynodont synapomorphy (Hopson \& Kitching, 2001), has not yet been described for any cynodont stemward of that clade. Abdala et al. (2019) recently reported a fused mandibular symphysis for the Permian Vetusodon, but Huttenlocker \& Sidor (2020) doubted the presence of this feature in this taxon and changed the coding of this character to 'absent' in their phylogenetic dataset. In BSPG 1934-VIII-7, a fused symphysis cannot be confirmed with certainty based on external examination, because of damage to the surface in the actual specimen. However, the CT-data (which shows no sign of a suture between the mandibular rami) and the fact that the jaw symphysis has remained in place as a single unit even after distortion 
395 (the dentaries frequently dislocate in therapsid skulls showing this style of compression) together 396 provide strong evidence that this structure is fused in Bolotridon (Fig. 8, 9).

397 In lateral view, the dentaries gently curve upwards at the symphysis. They consist of a

398 horizontal, tooth-bearing ramus, with its ventral margin being damaged on the right side, and a 399 posterodorsally sloping coronoid process, which is slightly damaged on both sides. The tip of the 400 coronoid process is located close to the postorbital bar and its posterior margin, which is better 401 preserved on the right side, and slopes posteroventrally to contact the postdentary bones, of 402 which only a portion of the right prearticular is preserved (Fig. 1-4, 8). The dentary houses three 403 incisors (only the left incisor arcade is complete; the second incisor on the right side has fallen out), one canine, and ten postcanines. Both the canine and postcanines in the right dentary are 405 preserved in place. In contrast, the left lower postcanine row is missing pc3 and pc4 and has been 406 slightly shifted inwards due to lateral compression. The left pc1, pc2 and canine are placed 407 somewhat anterior to their counterparts on the right side. As in the upper jaw, there is a short 408 diastema present between the lower canine and first lower postcanine. The lower postcanines are 409 generally poorly preserved, likely due to their appression and subsequent compression against 410 the upper jaw. In the right dentary, both the last and penultimate postcanines are similar in size, 411 but noticeably smaller than the other teeth with the exception of pc4. These two posteriormost 412 teeth and pc4 either have damaged crowns or are not yet fully erupted (Fig. 8). The small holes 413 visible on the ventral surface of the premaxilla just posterior to the upper incisor row are likely 414 not caused by taphonomically-induced impression of the lower incisors into the upper jaw, but 415 rather seem to be naturally present to accommodate the crowns of the enlarged lower teeth (Fig. 416 7B). Such holes for accommodating the lower incisors are also observed on the ventral surface of 417 the premaxilla in Thrinaxodon (e.g. Jasinoski, Abdala \& Fernandez, 2015: Fig. 7). 
418 A well-developed masseteric fossa for the adductor musculature in the posterior portion of

419 the horizontal ramus of the right dentary extends anteriorly to a point below the anterior margin 420 of the orbit at the level between the last and penultimate upper postcanines, with its anterior and 421 ventral margins being offset from the rest of the dentary by a pronounced lateral curvature 422 around the postdentary bar (Fig. 2A). The definition and extension of the masseteric fossa, as 423 well as the larger coronoid process with its tip being located close to the postorbital bar, closely 424 resemble the condition described for Thrinaxodon and more derived cynodonts, rather than what 425 is visible in the galesaurids Progalesaurus and Galesaurus in which the masseteric fossa is not 426 well defined and the coronoid process is not as large, or Permian taxa in which the fossa is 427 restricted to the coronoid process (Kemp, 1979; Abdala \& Damiani, 2004; Sidor \& Smith, 2004; 428 Ivakhnenko, 2013; Kammerer, 2016; Huttenlocker \& Sidor, 2020).

429 The splenial is present as a thin, anteroposteriorly elongated element positioned medial to 430 the horizontal ramus of the right dentary by which it is completely obscured from lateral view. 431 Anteriorly, it extends from the level of the root of the lower canine, where it contributes to the 432 mandibular symphysis, to a level near the posterior margin of the dentary where it underlies the 433 anterior tip of the prearticular (Fig. 4, 8A,C).

434 The right prearticular is broken and incomplete and only extends up to the posterior margin 435 of the coronoid process. Its anterior portion, which contacts the splenial anteriorly, rests medial 436 to the posterior margin of the dentary where it is overlapped by the ventral tip of the descending 437 transverse flange of the pterygoid (Fig. 2, 4, 8).

438 The angular, which usually forms the ventral and posterolateral portion of the lower jaw, is 439 also broken and incompletely preserved in BSPG 1934-VIII-7. Its anterior portion, which is only 440 preserved on the left side, has been strongly shifted anteriorly extending medially along the 
441 tooth-bearing horizontal ramus of the dentary. An articular facet is visible on its posterodorsal

442 surface to accommodate the prearticular, which is (with the exception of a small fragment) not

443 preserved on the left side. The reflected lamina of the angular is completely missing in this

444 specimen (Fig. 8).

445

\section{Discussion}

447

448 Phylogeny of early cynodonts

449 The parsimony analysis recovered 24 most parsimonious trees with a tree length of 256

450 (consistency index $=0.598$, retention index $=0.809$ ). Generally, the strict consensus and

451 Bayesian inference majority rule topologies (Fig. 10) are similar to those of Huttenlocker \&

452 Sidor (2020), but the interrelationships of epicynodonts in our parsimony analysis are better

453 resolved after including Bolotridon. Topology for non-epicynodont cynodonts is identical to that

454 of Huttenlocker \& Sidor (2020), with charassognathids and Dvinia recovered in a clade at the

455 base of Cynodontia and Procynosuchus crownward of them.

456 As in the earlier analysis, Abdalodon diastematicus and Nshimbodon muchingaensis are

457 recovered as sister-taxa with extremely high support. These two taxa, the former known from a

458 small, dorsoventrally crushed skull from the South African Endothiodon AZ and the latter from a

459 relatively well-preserved skull from the Zambian Madumabisa Mudstone Formation, are

460 exceedingly similar, and the diagnostic features of the latter cited by Huttenlocker \& Sidor

461 (2020) are all questionable. These authors differentiated Nshimbodon from Abdalodon by a

462 gentler anteroventral slope of the rostrum and proportionally deeper dentary ramus. However, the

463 diagnostic value of these characters is rendered dubious by extreme dorsoventral compression in

464 the holotype of $A$. diastematicus, which has altered the snout profile and relative height of the 
465 dentary. Potential ontogenetic variation in jaw robusticity also should be considered, as the 466 holotype of A. diastematicus represents a somewhat smaller specimen (5.61 $\mathrm{cm}$ skull length) 467 than that of $N$. muchingaensis $(7.0 \mathrm{~cm})$. Other listed autapomorphies for Nshimbodon include 468 tooth count and the presence of a series of neurovascular pits on the dentary, but in these features 469 it accords closely with Abdalodon (Kammerer, 2016). Here, we synonymize Nshimbodon with 470 Abdalodon, albeit tentatively retaining the species muchingaensis considering geographic and 471 probable stratigraphic separation from A. diastematicus. Additional specimens from Zambia and 472 South Africa will be required to determine whether even specific separation is warranted. 473 As in the analyses of Huttenlocker \& Sidor (2020), Epicynodontia and Eucynodontia are 474 recovered with strong support in our analyses. The strict consensus tree recovers the Triassic 475 galesaurids Galesaurus and Progalesaurus at the base of Epicynodontia, followed by the 476 Permian Cynosaurus (sometimes considered a galesaurid) and Vetusodon, here in a sister-taxon 477 relationship and occupying a position crownward of the latter taxa. This contrasts with the strict 478 consensus of Huttenlocker \& Sidor (2020), in which the majority of non-eucynodont 479 epicynodont taxa form an unresolved polytomy. In our Bayesian tree, galesaurids and Vetusodon $480+$ Cynosaurus form an unresolved polytomy at the base of Epicynodontia as in the Bayesian tree 481 of Huttenlocker \& Sidor (2020). The slightly more crownward position of Cynosaurus in our 482 strict consensus tree differs from what was suggested by previous workers, who recovered 483 Cynosaurus as stemward to Galesaurus and Progalesaurus (e.g., Abdala, 2007; Kammerer, 484 2016; Van den Brandt \& Abdala, 2018; Abdala et al., 2019), but this position lacks unambiguous 485 apomorphies supporting it. The clade formed by Vetusodon and Cynosaurus is recovered with 486 low support in our parsimony analysis, but modest support in the Bayesian analysis.

487 Both the parsimony and Bayesian analyses recover Bolotridon as the sister-taxon of 
488 Eucynodontia (Fig. 10). Thrinaxodon is recovered in a polytomy with Nanictosaurus + 489 Platycraniellus and Bolotridon + Eucynodontia in both analyses. The clade uniting Bolotridon + 490 Eucynodontia has modest support in the parsimony analysis, but is recovered with strong support 491 in the Bayesian analysis, despite many unknown characters as a result of the physical 492 incompleteness of BSPG 1934-VIII-7. Evidence for a sister-taxon relationship between 493 Bolotridon and Eucynodontia is provided by only a single but very important character: fusion of 494 the mandibular symphysis, which was historically considered a eucynodont synapomorphy 495 (Hopson \& Kitching, 2001). A position outside of Eucynodontia is supported by the morphology 496 of the dentary symphysis, which is low and gently sloping in Bolotridon, as in more stemward 497 cynodonts. In eucynodonts the dentary symphysis is tall, steeply-sloped and forms a distinct 498 'chin'. A similar morphology was also described for the dentary symphysis of the Permian 499 Vetusodon and Cynosaurus, but this is here optimized as convergence (e.g., Van den Brandt \& 500 Abdala, 2018; Abdala et al., 2019; Huttenlocker \& Sidor, 2020: Supplemental Information). 501

\section{Comparison of Bolotridon with other cynodonts}

503 The new data obtained from the CT-scan permit a better resolved for Bolotridon than in the 504 phylogenetic analysis of Sidor \& Smith (2004), where it was nested in a polytomy with 505 Galesauridae and a clade consisting of the more derived epicynodonts Thrinaxodon and 506 Platycraniellus. Inclusion of Bolotridon in Galesauridae is not supported by our results. In 507 addition to a fused mandibular symphysis, which is not known from any late Permian or Early 508 Triassic cynodont, a crownward position for Bolotridon relative to the galesaurids is supported 509 by three additional characters in our analysis. One of these characters uniting Bolotridon with the 510 more derived epicynodonts Thrinaxodon, Nanictosaurus, Platycraniellus, and eucynodonts to the 
511 exclusion of galesaurids is the presence of a well-developed masseteric fossa extending to the

512 angle of the horizontal ramus of the dentary. The other two characters show a more complex

513 distribution, being shared with the crownward epicynodonts Thrinaxodon and Nanictosaurus but

514 also stemward Permian cynodonts, and not with with eucynodonts or galesaurids. These are the

515 absence of a strongly recurved main cusp on the posterior postcanines (the presence of this

516 character in Progalesaurus and Galesaurus is interpreted as having evolved convergently from

517 eucynodonts [Huttenlocker \& Sidor, 2020: Supplemental Information]) and the presence of a

518 lingual cingulum in the lower postcanines. The absence of this feature in the lower postcanines

519 of Progalesaurus and Galesaurus might have evolved independently from eucynodonts as well,

520 but since this character is so far uncertain in Vetusodon, Cynosaurus, and Charassognathidae,

521 this cannot be confirmed.

522 Although endocranial characters have been described for various therapsids in CT-assisted

523 studies in recent years, with special focus on cynodonts as the therapsid clade ancestral to (and

524 including) mammals (e.g., Hillenius, 1994; Kemp, 2009; Rodrigues, Ruf \& Schultz, 2013, 2014;

525 Rodrigures et al., 2018; Benoit et al., 2016, 2017a, b, c, 2018, 2019; Araújo et al., 2017, 2018;

526 Crompton, Musinsky \& Owerkowicz, 2015; Crompton et al., 2017; Bendel et al., 2018; Pusch,

527 Kammerer \& Fröbisch, 2019; Pusch et al., 2020; Huttenlocker \& Sidor, 2020), they still remain

528 understudied compared to the well-known external craniodental features in synapsids and thus

529 have been largely ignored in phylogenetic analyses. The data matrix of Huttenlocker \& Sidor

530 (2020) is the only matrix so far including newly adapted information from Benoit et al. (2017a)

531 about the rarely preserved orbithosphenoid in therapsids. Despite damage and incomplete

532 preservation of BSPG 1934-VIII-7, we were able to describe a few endocranial characters for

533 Bolotridon that are consistent with an epicynodont position for this taxon. Those characters 
534 include a maxillary canal that would have arisen from a relatively small maxillary antrum

535 (antrum visible in CT-scan, but canal itself not resolvable due to damage) and a possible

536 maxilloturbinal ridge extending forward beyond the opening of the lacrimal. The presence of the

537 latter is rendered somewhat uncertain by poor preservation and CT-resolution in this region of

538 the snout; as mentioned in our description a ridge appears to be present but could also represent a

539 crack. Ridges that would have served as attachment point for cartilaginous maxilloturbinals have

540 been described so far only for the epicynodonts Galesaurus and Thrinaxodon and for

541 eucynodonts such as the cynognathian Massetognathus and the probainognathian

542 Probainognathus (Crompton, 2013; Crompton, Musinsky \& Owerkowicz, 2015; Crompton et al.

543 2017; Pusch, Kammerer \& Fröbisch, 2020); they are absent in the non-epicynodonts Abdalodon

544 muchingaensis (Huttenlocker \& Sidor, 2020) and Procynosuchus delaharpeae (Kemp, 1979).

545 Based on its position crownward of Galesaurus and Thrinaxodon in our analysis, presence of a

546 maxilloturbinal ridge can be inferred for Bolotridon, even if the current record is less than

547 definitive. A relatively small maxillary antrum from which the branching maxillary canal

548 extends forward has also been described for Galesaurus and Thrinaxodon and is additionally

549 present in basal probainognathian eucynodonts such as Ecteninion and Lumkuia. This contrasts

550 with what is observed in the cynognathians Trirachodon and Massetognathus, in which the

551 antrum is massive by comparison, and more crownward probainognathians, in which the

552 maxillary antrum is separated from the maxillary canal and resembles the mammaliaform pattern

553 (Benoit et al., 2016, 2019; Crompton et al., 2017; Pusch, Kammerer \& Fröbisch, 2019).

554 However, data concerning the morphology of the maxillary canal and antrum of cynodonts

555 stemward of Galesaurus are still lacking, so it is uncertain whether a relatively small antrum

556 represents a derived condition among early cynodonts or if this feature is conservative among 
557 basal taxa of this clade. Denser sampling of endocranial features of basal cynodonts is needed to

558 test where this and other mammalian features might have first evolved.

559

560 A unique fauna of small-bodied therapsids in the Trirachodon-Kannemeyeria Subzone

561 The Trirachodon-Kannemeyeria Subzone of the Cynognathus AZ is the most fossil- and species-

562 rich of the three Cynognathus AZ subzones. Therapsids in this subzone are represented by the

563 abundant dicynodont Kannemeyeria simocephalus, the rare therocephalians Microgomphodon

564 oligocynus and Bauria cynops, and cynodonts such as the common Cynognathus crateronotus,

565 Diademodon tetragonus, Trirachodon berryi, and Trirachodon/Cricodon kannemeyeri (the latter

566 first appearing at the top of this subzone) (Abdala, Hancox \& Neveling, 2005; Abdala \& Ribeiro,

567 2010; Smith, Rubidge \& Van der Walt, 2012: Table 2.5; Hancox, Neveling \& Rubidge, 2020). In

568 addition to the usual occurrences of Trirachodon, Cynognathus, Diademodon, and

569 Kannemeyeria at Lady Frere, this area (consisting of both the Commonage and nearby localities

570 like Lumku Mission in Chris Hani District Municipality) yields unique records of small-bodied

571 therapsid taxa including the dicynodont Kombuisia frerensis, the basal cynodont Bolotridon

572 frerensis, and the early probainognathian Lumkuia fuzzi (Broili \& Schröder, 1934; Kitching,

573 1973; Hotton, 1974; Hopson \& Kitching, 2001; Fröbisch, 2007; Abdala, Hancox \& Neveling,

574 2005; Abdala \& Ribeiro, 2010; Smith, Rubidge \& Van der Walt, 2012: Table 2.5; Hancox,

575 Neveling \& Rubidge, 2020).

576 These seemingly anachronistic faunal elements (representing both 'relict' taxa like the

577 emydopoid dicynodont Kombuisia and the non-eucynodont Bolotridon, and an early

578 representative of the later-radiating cynodont clade Probainognathia in Lumkuia) highlight the

579 complex and transitional nature of the Cynognathus AZ fauna. Gaps in our knowledge of small- 
580 bodied taxa throughout the Triassic make confident evaluation of the stratigraphic ranges of 581 some groups difficult, complicating our understanding of what is truly 'relictual' vs. just rarely 582 preserved. For example, the cynodonts Bolotridon and Lumkuia are not known from localities 583 outside of the area surrounding Lady Frere, and are restricted to the Trirachodon-Kannemeyeria 584 Subzone of the Cynognathus AZ. The type species of the rare dicynodont Kombuisia (K.

585 frerensis), which is only known from two specimens from the Lady Frere locality, is also 586 restricted to the Trirachodon-Kannemeyeria Subzone of the Cynognathus AZ. However, a 587 second species of the genus, Kombuisia antarctica from the lower Fremouw Formation in 588 Antarctica, extends the known stratigraphic range of Kombuisia into rocks that are equivalent in 589 age to the Lower Triassic Lystrosaurus declivis AZ of South Africa (Fröbisch, 2007; Fröbisch, 590 Angielczyk \& Sidor, 2010; Botha \& Smith, 2020; Hancox, Neveling \& Rubidge, 2020). 591 It is possible that the apparent restriction of these taxa to the area surrounding Lady Frere 592 is an artifact of unusual preservational conditions; something lending itself to the preservation of 593 small-bodied, rare taxa not recorded at other Cynognathus AZ localities. Complicating this 594 interpretation somewhat is the broader geographic range of certain otherwise-comparable coeval 595 therapsids. The bauriid Bauria is also relatively small (basal skull length $\sim 12 \mathrm{~cm}$ ), is in some 596 ways a 'relict' (being among the geologically youngest therocephalians), and occurs only in the

597 Trirachodon-Kannemeyeria Subzone, but is much more widely distributed across the Karoo 598 Basin (Kitching, 1973; Abdala et al., 2014; Hancox, Neveling \& Rubidge, 2020). Another 599 contemporaneous bauriid, Microgomphodon, exhibits substantially broader stratigraphic and 600 geographic ranges, occurring from the lower Langbergia-Garjainia Subzone to the Trirachodon601 Kannemeyeria Subzone in the South African Cynognathus AZ and also the upper Omingonde 602 Formation of Namibia (Abdala et al., 2014; Hancox, Neveling \& Rubidge, 2020). The greatest 
603 geographic and stratigraphic range for a Cynognathus AZ tetrapod, however, is that of the small 604 parareptile Palacrodon browni. Originally known from the Cynognathus AZ of South Africa, 605 this taxon was later discovered in the lower Fremouw Formation of Antarctica (which correlates 606 chronostratigraphically with the Lower Triassic Lystrosaurus declivis AZ of South Africa) and 607 the Upper Triassic Chinle Formation of northeastern Arizona, USA (Kligman, Marsh \& Parker, 608 2018; Botha \& Smith, 2020; Hancox, Neveling \& Rubidge, 2020). The presence of Palacrodon 609 in the middle Norian of the southwest United States extends the stratigraphic range of this genus 610 by at least 15 million years, indicating remarkable persistence. Taken as a whole, these examples 611 suggest that small-bodied Triassic tetrapods are greatly undersampled in the record. This is 612 particularly likely to bias local estimates of diversity and richness, where localities may record 613 the most abundant small-bodied taxa (e.g., trirachodontid cynodonts in the Cynognathus AZ), but 614 with rarer small-bodied members of these assemblages unlikely to be preserved and/or collected.

615 This is well-illustrated by the extreme paucity of known Palacrodon fossils, despite its

616 stratigraphic duration of $\sim 35$ million years and Pangean distribution, and accentuated by the fact

617 that the survival of emydopoid dicynodonts and non-eucynodont cynodonts into the Middle 618 Triassic would be completely unknown if not for the exceptional record at Lady Frere. What 619 makes this site exceptional is currently uncertain; whether the paleoenvironment favored by 620 Kombuisia and Bolotridon was not present in other Cynognathus AZ localities, whether local 621 depositional environments favored preservation of small-bodied animals, or whether some 622 combination of these and/or collection bias explains its unusual local fauna is uncertain. Most of 623 the published records from the area are from historical collections, and new, detailed lithological 624 and stratigraphical studies are needed to understand the local environment and preservational 625 regime in order to get answers. 


\section{Conclusions}

627

628 Our redescription of the enigmatic basal cynodont Bolotridon frerensis, based on a computed 629 tomographic (CT) reconstruction of the specimen BSPG 1934-VIII-7, provides new information 630

\section{Institutional Abbreviations}

\section{8}

649 BSPG Bayerische Staatssammlung für Paläontologie und Geologie, Munich, Germany.

650 NHMUK PV Natural History Museum, Vertebrate Palaeontological Collection, London, UK. 


\section{Acknowledgements}

652

653

654

655

656

657

658

659

660

661

662

663

664

665

666

667

668

669

670

671

672

673

674

675

676

677

678

679

680

681

682

683

684

685

686

687

We wish to thank Oliver Rauhut (Bayerische Staatssammlung für Paläontologie und Geologie,

Munich, Germany) for the loan of BSPG 1934-VIII-7 and Kristin Mahlow (CT-Laboratory,

Museum für Naturkunde, Berlin, Germany) for scanning the specimen. LCP would like to thank

Mark MacDougall (Museum für Naturkunde, Berlin, Germany) and Neil Brocklehurst

(University of Oxford, United Kingdom) for their brief introductions into PAUP* and MrBayes.

Furthermore, we would like to thank Ken Angielczyk and Jim Hopson for their thorough and

constructive reviews of the manuscript and Brandon Hedrick for work as editor.

\section{References}

Abdala F. 2007. Redescription of Platycraniellus elegans (Therapsida, Cynodontia) from the lower Triassic of South Africa, and the cladistic relationships of eutheriodonts. Palaeontology 50(3):591-618 DOI 10.1111/j.1475-4983.2007.00646.x.

Abdala F, Allinson M. 2005. The taxonomic status of Parathrinaxodon proops (Therapsida: Cynodontia), with comments on the morphology of the palate in basal cynodonts. Palaeontologia africana 41:45-52.

Abdala F, Giannini N. 2002. Chiniquodontid cynodonts: systematic and morphometric considerations. Palaeontology 45(6): 1151-1170.

Abdala F, Damiani R. 2004. Early development of the mammalian superficial masseter muscle in cynodonts. Paleontologia africana 40:23-29.

Abdala F, Ribeiro AM. 2010. Distribution and diversity patterns of Triassic cynodonts (Therapsida, Cynodontia) in Gondwana. Paleogeography, Paleoclimatology, Paleoecology 286(2-3):202-217 DOI 10.1016/j.palaeo.2010.01.011.

Abdala F, Hancox PJ, Neveling J. 2005. Cynodonts from the uppermost Burgersdorp Formation, South Africa, and their bearing on the biostratigraphy and correlation of the Triassic Cynognathus Assemblage Zone. Journal of Vertebrate Paleontology 25(1):192-199.

Abdala F, Jasinoski S, Fernandez V. 2013. Ontogeny of the Early Triassic cynodont Thrinaxodon liorhinus (Therapsida): dental morphology and replacement. Journal of Vertebrate Paleontology 33(6):1408-1431 DOI: 10.1080/02724634.2013.775140.

Abdala F, Gaetano LC, Smith RMH, Rubidge BS. 2019. A new large cynodont from the late Permian (Lopingian) of the South African Karoo Basin and its phylogenetic significance. Zoological Journal of the Linnean Society 186(4): 983-1005 DOI: 10.1093/zoolinnean/zlz004. Abdala F, Jashashvili T, Rubidge BS, van den Heever J. 2014. New material of Microgomphodon oligocynus (Eutherapsida, Therocephalia) and the taxonomy of southern African Bauriidae. In:

Peer) reviewing PDF | (2021:03:58981:1:1:NEW 4 May 2021) 
688

Kammerer CF, Angielczyk KD, Fröbisch J, eds. Early Evolutionary History of the Synapsida. Dordrecht:Springer, 209-231.

Angielczyk KD, Kammerer CF. 2018. Non-Mammalian synapsids: the deep roots of the mammalian family tree. In: Zachos FE, Asher RJ, eds. Handbook of Zoology: Mammalian Evolution, Diversity and Systematics. Berlin/Boston: Walter de Gruyter GmbH \& Co. KG, 117 $-198$.

Araújo RM, Fernandez V, Polcyn MJ, Fröbisch J, Martins RMS. 2017. Aspects of gorgonopsian paleobiology and evolution: insights from the basicranium, occiput, osseous labyrinth, vasculature, and neuroanatomy. PeerJ 5:e3119.

Araújo, RM, Fernandez V, Rabbitt RD, Ekdale EG, Antunes MT, Castanhinha R, Fröbisch J, Martins RMS. 2018. Endothiodon cf. bathystoma (Synapsida: Dicynodontia) bony labyrinth anatomy, variation and body mass estimates. PLoS ONE 13:e0189883.

Battail B. 1991. Les cynodontes (Reptilia, Therapsida): une phylogénie. Bulletin du Muséum d'histoire naturelle 13:17-105.

Bendel E-M, Kammerer CF, Kardjilov N, Fernandez V, Fröbisch J. 2018. Cranial anatomy of the gorgonopsian Cynariops robustus based on CT-reconstruction. PLoSONE 13(11):e0207367 DOI 10.1371/journal.pone.0207367.

Benoit J, Angielczyk KD, Miyamae JA, Manger P, Fernandez V, Rubidge B, 2018. Evolution of facial innervation in anomodont therapsids (Synapsida): Insights from X-ray computerized microtomography. Journal of Morphology 279:1-29.

Benoit J, Jasinoski SC, Fernandez V, Abdala F. 2017a. The mystery of a missing bone: revealing the orbitosphenoid in basal Epicynodontia (Cynodontia, Therapsida) through computed tomography. The Science of Nature 104(7-8):66 DOI: 10.1007/s00114-017-1487-z.

Benoit J, Manger PR, Fernandez V, Rubidge BS. 2017b. The bony labyrinth of the late Permian Biarmosuchia: palaeobiology and diversity in non-mammalian Therapsida. Palaeontologia Africana 52:58-77.

Benoit J, Manger PR, Norton L, Fernandez V, Rubidge BS. 2017c. Synchrotron scanning reveals the paleoneurology of the head-butting Moschops capensis (Therapsida, Dinocephalia). PeerJ 5:e3496.

Benoit J, Manger PR, Rubidge BS. 2016. Palaeoneurological clues to the evolution of defining mammalian soft tissue traits. Scientific Reports 6:25604 DOI 10.1038/srep25604.

Benoit J, Ruf I, Miyamae JA, Fernandez V, Rodrigues PG, Rubidge BS. 2019. The evolution of the maxillary canal in probainognathia (Cynodontia, Synapsida): reassessment of the homology of the infraorbital foramen in mammalian ancestors. Journal of Mammalian Evolution 1-20 DOI 10.1007/s10914-019-09467-8.

Botha J, Smith RMH. 2020. Biostratgraphy of the Lystrosaurus declivis Assemblage Zone (Beaufort, Group, Karoo Supergroup), South Africa. South African Journal of Geology 123(2):207-216 DOI 10.25131/saig.123.0015.

Botha J, Abdala F, Smith RMH. 2007. The oldest cynodont: new clues on the origin and diversification of the Cynodontia. Zoological Journal of the Linnean Society 149(3):477-492 DOI 10.1111/j.1096-3642.2007.00268.x.

Brink AS, Kitching JW. 1953. On some new Cynognathus zone specimens. Palaeontologia Africana 1:29-48

Broili F, Schröder J. 1934. Beobachtungen an Wirbeltieren der Karrooformation. II. Über den Cynodontier Tribolodon frerensis Seeley. Sitzungsberichte der Bayerischen Akademie der Wissenschaften, 163-177.

Peer) reviewing PDF | (2021:03:58981:1:1:NEW 4 May 2021) 
734

735

736

737

738

739

740

741

742

743

744

745

746

747

748

749

750

751

752

753

754

755

756

757

758

759

760

761

762

763

764

765

766

767

768

769

770

771

772

773

774

775

776

777

Broom R. 1937. A further contribution to our knowledge of the fossil reptiles of the Karroo. Proceedings of the Zoological Society of London B 107:299-318.

Coad BW. 1977. On the nomenclature of the genus name Tribolodon (Osteichthyes and Reptilia). Journal of Paleontology 51:1046-1047.

Crompton AW. 2013. Evolution of the mammalian nose, presentation. Available at https://crompton.oeb.harvard.edu/evolution-mammalian-nose-presentation (accessed at 10 November 2020).

Crompton AW, Musinsky C, Owerkowicz T. 2015. Evolution of the mammalian nose. In: Dial K, Shubin N, Brainerd E, eds. Great Transformations in Vertebrate Evolution. Chicago: University of Chicago Press, 189-203.

Crompton AW, Owerkowicz T, Bhullar B-AS, Musinsky C. 2017. Structure of the nasal region of nonmammalian cynodonts and mammaliaforms: Speculations on the evolution of mammalian endothermy. Journal of Vetrebrate Paleontology 37(1):e126911 DOI 10.1080/02724634.2017.1269116.

Fourie S. 1974. The cranial morphology of Thrinaxodon liorhinus Seeley. Annals of the South African Museum 65:337-400.

Fröbisch J. 2007. The cranial anatomy of Kombuisia frerensis Hotton (Synapsida, Dicynodontia) and a new phylogeny of anaomodont therapsids. Zoological Journal of the Linnean Society 150:117-144.

Fröbisch J, Angielczyk KD, Sidor CA. 2010. The Triassic dicynodont Kombuisia (Synapsida, Anomodontia) from Antarctica, a refuge from the terrestrial Permian-Triassic mass extinction. Naturwissenschaften 97:187-196.

Hancox PJ, Neveling J, Rubidge BS. 2020. Biostratigraphy of the Cynognathus Assemblage Zone (Beaufort Group, Karoo Supergroup), South Africa. South African Journal of Geology 123(2):217-238 DOI 10.251317saig.123.006.

Hendrickx C, Gaetano LC, Choiniere JN, Mocke H, Abdala F. 2020. A new traversodontid cynodont with a peculiar postcanine dentition from the Middle/Late Triassic of Namibia and dental evolution in basal gomphodonts. Journal of Systematic Paleontology 18(20):1669-1706 DOI 10.1080/14772019.2020.1804470.

Hillenius WJ. 1994. Turbinates in therapsids: evidence for Late Permian origins of mammalian endothermy. Evolution 48:207-229.

Hillenius WJ. 2000. Septomaxilla of nonmammalian synapsids: soft-tissue correlates and a new functional interpretation. Journal of Morphology 245:29-50.

Hopson JA. 1991. Systematics on the nonmammalian Synapsida and implications for patterns of evolution in synapsids. In: Schultze H-P, Trueb L, eds. Origins of the Higher Groups of Tetrapods: Controversy and Consensus. Ithaca, NY: Comstock Publishing Associates, 635693.

Hopson JA, Kitching JW. 1972. A revised classification of cynodonts (Reptilia; Therapsida). Palaeontologia africana 14:71-85.

Hopson JA, Kitching JW. 2001. A probainognathian cynodont from South Africa and the phylogeny of nonmammalian cynodonts. Bullentin of the Museum of Comperative Zoology 156(1):5-35.

Hotton N. 1974. A new dicynodont (Reptilia, Therapsida) from Cynognathus Zone deposits of South Africa. Annals of the South African Museum 64:157-165.

Peer) reviewing PDF | (2021:03:58981:1:1:NEW 4 May 2021) 
778

779

780

781

782

783

784

785

786

787

788

789

790

791

792

793

794

795

796

797

798

799

800

801

802

803

804

805

806

807

808

809

810

811

812

813

814

815

816

817

818

819

820

821

822

Huttenlocker AK, Sidor CA. 2020. A basal nonmammaliaform cynodont from the Permian of Zambia and the origins of mammalian endocranial and postcranial anatomy. Journal of Vertebrate Paleontology e1827413 DOI 10.1080/ 02724634.2020.1827413.

Ivakhnenko MF. 2013. Cranial morphology of Dvinia prima Amalitzky (Cynodontia, Thermomorpha). Paleontological Journal 47(2):210-222.

Jasinoski SC, Abdala F, Fernandez V. 2015. Ontogeny of the early Triassic cynodont Thrinaxodon liorhinus (Therapsida): cranial morphology. The Anatomical Record 298:1440-1464.

Kammerer CF. 2016. A new taxon of cynodont from the Tropidostoma Assemblage Zone (Upper Permian) of South Africa, and the early evolution of Cynodontia. Papers in Palaeontology 2(3):387-397 DOI 10.5061/dryad.52064.

Kammerer CF. 2017. Anatomy and relationships of the South African gorgonopsian Arctops (Therapsida, Theriodontia). Papers in Paleontology 3(4):583-611 DOI 10.1002/spp2.1094.

Kemp TS. 1979. The primitive cynodont Procynosuchus: functional anatomy of the skull and relationships. Philosophical Transactions of the Royal Society of London B 285:73-122.

Kemp TS. 2005. The Origin and Evolution of Mammals. New York: Oxford University Press.

Kemp TS. 2009. The endocranial cavity of a nonmammalian eucynodont, Chiniquodon theotonicus, and its implications for the origin of the mammalian brain. Journal of Vertebrate Paleontology 29(4):1188-1198.

Kitching JW. 1963. Notes on some fossil pockets and bone beds in the Cynognathus-Zone in the Burghersdorp and Lady Frere districts. Paleontologia africana 8:113-118.

Klingman BT, Marsh AD, Parker WG. 2018. First record of diapsid Palacrodon from the Norian, Late Triassic Chinle Formation of Arizona, and their biogeographic implications. Acta Palaeontologica Polonica 63(1): 117-127.

Lewis PO. 2001. A likelihood approach to estimating phylogeny from discrete morphological character data. Systematic Biology 50(6):913-925.

Lukic-Walther M, Brocklehurst N, Kammerer CF, Fröbisch J. 2019. Diversity patterns of nonmammalian cynodonts (Synapsida, Therapsida) and the impact of taxonomic practice and research history on diversity estimates. Paleobiology 45(1):1-14 DOI 10.1017/pab.2018.38.

Pusch LC, Kammerer CF, Fröbisch J. 2019. Cranial anatomy of the early cynodont Galesaurus planiceps and the origin of mammalian endocranial characters. Journal of Anatomy 234(5):592-621 DOI 10.1111/joa.12958.

Pusch LC, Ponstein J, Kammerer CF, Fröbisch J. 2020. Novel endocranial data on the early therocephalian Lycosuchus vanderrieti underpin high character variability in early theriodont evolution. Frontiers in Ecology and Evolution 7:464 DOI 10.3389/fevo.2019.00464.

Rodrigues PG, Ruf I, Schultz CL. 2013. Digital reconstruction of the otic region and inner ear of the non-mammalian cynodont Brasilitherium riograndensis (Late Triassic, Brazil) and its relevance to the evolution of the mammalian ear. Journal of Mammalian Evolution 20:291307.

Rodrigues PG, Ruf I, Schultz, CL. 2014. Study of a digital cranial endocast of the nonmammaliaform cynodont Brasilitherium riograndensis (Later Triassic, Brazil) and its relevance to the evolution of the mammalian brain. Paläontologische Zeitschrift 88:329-352.

Rodrigues PG, Martinelli AG, Schultz CL, Corfe IJ, Gill AG, Soares MB, Rayfield EJ. 2018. Digital cranial endocast of Riograndia guaibensis (Late Triassic, Brazil) sheds light on the evolution of the brain in non-mammalian cynodonts. Historical Biology DOI 10.1080/08912963.2018.1427742.

Peer) reviewing PDF | (2021:03:58981:1:1:NEW 4 May 2021) 
823 Ronquist F, Huelsenbeck JP. 2003. MrBayes 3: Bayesian phylogenetic inference under mixed

824

825

826

827

828

829

830

831

832

833

834

835

836

837

838

839

840

841

842

843

844

845

846

847

848

849

850

851

852

853

854

855 models. Bioinformatics 19(2):1572-1574.

Rowe T, Carlson W, Bottorff W. 1995. Thrinaxodon: digital atlas of the skull CD-ROM (Second Edition for Windows and Macintosh platforms). Austin, TX: University of Texas Press.

Seeley HG. 1894. Researches on the structure, organisation, and classification of the fossil Reptilia. Part IX., Section 1. On the Therosuchia. Philosophical Transactions of the Royal Society Series B 185:987-1018.

Seeley HG. 1895. Researches on the structure, organisation, and classification of the fossil Reptilia. Part IX., Section 5. On the Skeleton in New Cynodontia from the Karroo Rocks. Philosophical Transactions of the Royal Society Series B 186:59-148.

Sidor CA, Smith RMH. 2004. A new galesaurid (Therapsida: Cynodontia) from the Lower Triassic of South Africa. Palaeontology 47:535-556.

Sigurdsen T. 2006. New features of the snout and orbit of a therocephalian therapsid from South Africa. Acta Palaeontologia Polonica 51(1):63-75.

Smith R, Rubidge B, Van der Walt M. 2012. Therapsid biodiversity patterns and paleoenvironments of the Karoo Basin, South Africa. In: Chinsamy-Turan A, ed. Forerunners of Mammals: Radiation, Histology, Biology. Bloomington: Indiana University Press, 31-62.

Swofford DL. 2003. PAUP*. Phylogenetic analysis using parsimony (and other methods). Sunderland: Sinauer Associates.

Tatarinov LP. 1968. Morphology and systematics of the northern Dvinia cynodonts (Reptilia, Therapsida; Upper Permian). Postilla 125: 1-51.

Van den Brandt MJ, Abdala F. 2018. Cranial morphology and phylogenetic analysis of Cynosaurus suppostus (Therapsida, Cynodontia) from the upper Permian of the Karoo Basin, South Africa. Palaeontologia africana 52:201-221.

Van Heerden J, Rubidge B. 1990. The affinities of the early cynodont reptile Nanictosaurus. Palaeontologia africana 27:41-44.

Viglietti PA. 2020. Biostratigraphy of the Daptocephalus Assemblage Zone (Beaufort Group, Karoo Supergroup), South Africa. South African Journal of Geology 123(2):191-206 DOI 10.25131/sajg.123.0014. 
Figure 1

BSPG 1934-VIII-7 in dorsal view.

(A) Photograph and (B) 3D reconstruction of the specimen. Abbreviations: C, upper canine; $d$, dentary; fr, frontal; ju, jugal; mx, maxilla; na, nasal; pa, parietal; pmx, premaxilla; po, postorbital; pra, prearticular; prf, prefrontal; sq?, squamosal?. Photograph in (A) by Christian F. Kammerer. Image of the 3D reconstructed skull in (B) by Luisa C. Pusch. 
A

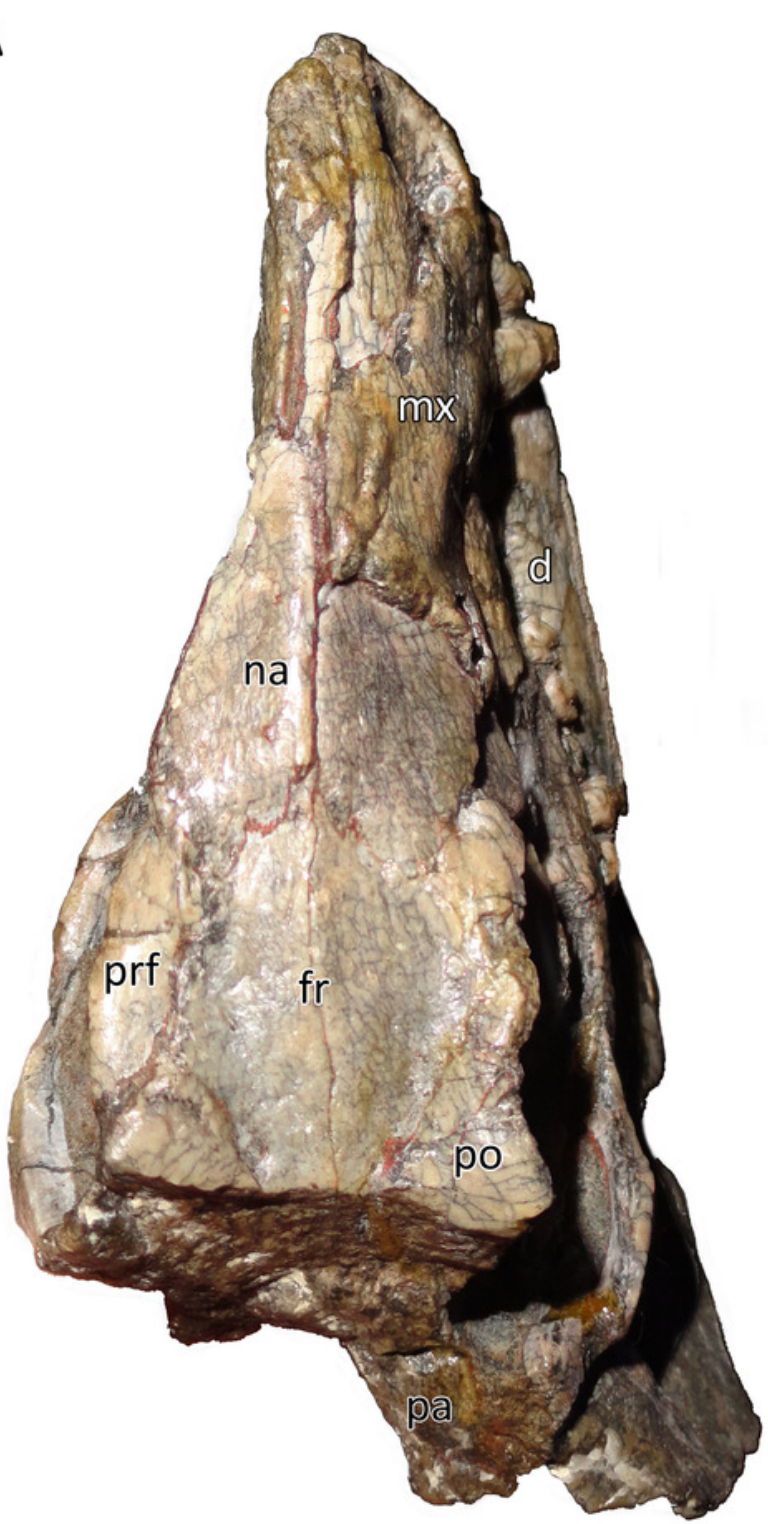

$1 \mathrm{~cm}$
B

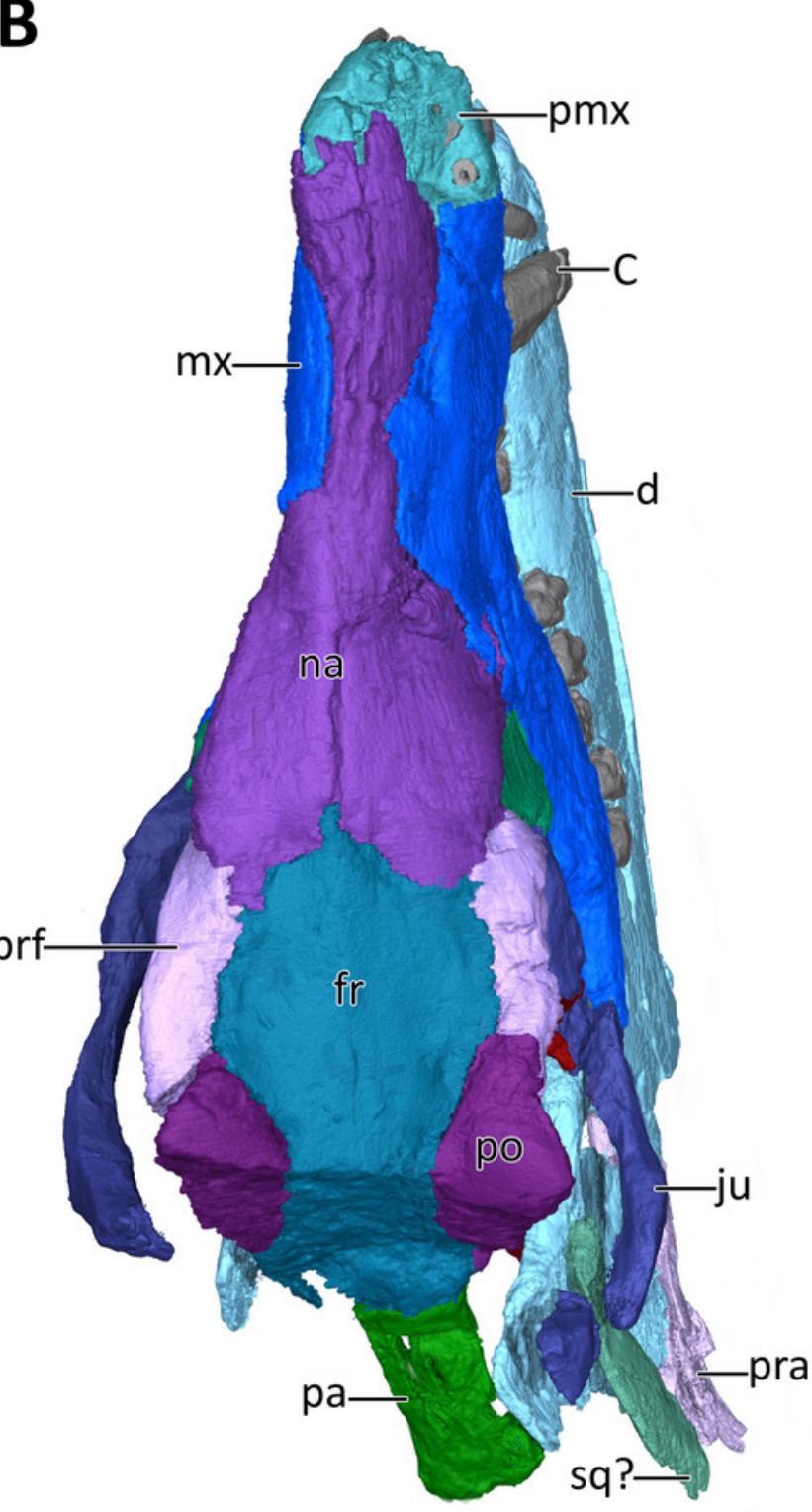

$1 \mathrm{~cm}$ 


\section{Figure 2}

BSPG 1934-VIII-7 in right lateral view.

(A) Photograph and (B) 3D reconstruction of the specimen. Abbreviations: $\mathrm{C}$, upper canine; $\mathrm{cp}$, coronoid process; d, dentary; fr, frontal; Is, upper incisors; ju, jugal; la, lacrimal; mf, masseteric fossa; mx, maxilla; na, nasal; pa, parietal; PCs, upper postcanines; pmx, premaxilla; pnp, prenasal process of the premaxilla; po, postorbital; pra, prearticular; prf, prefrontal; sq?, squamosal?. Photograph in (A) by Christian F. Kammerer. Image of the 3D reconstructed skull in (B) by Luisa C. Pusch. 


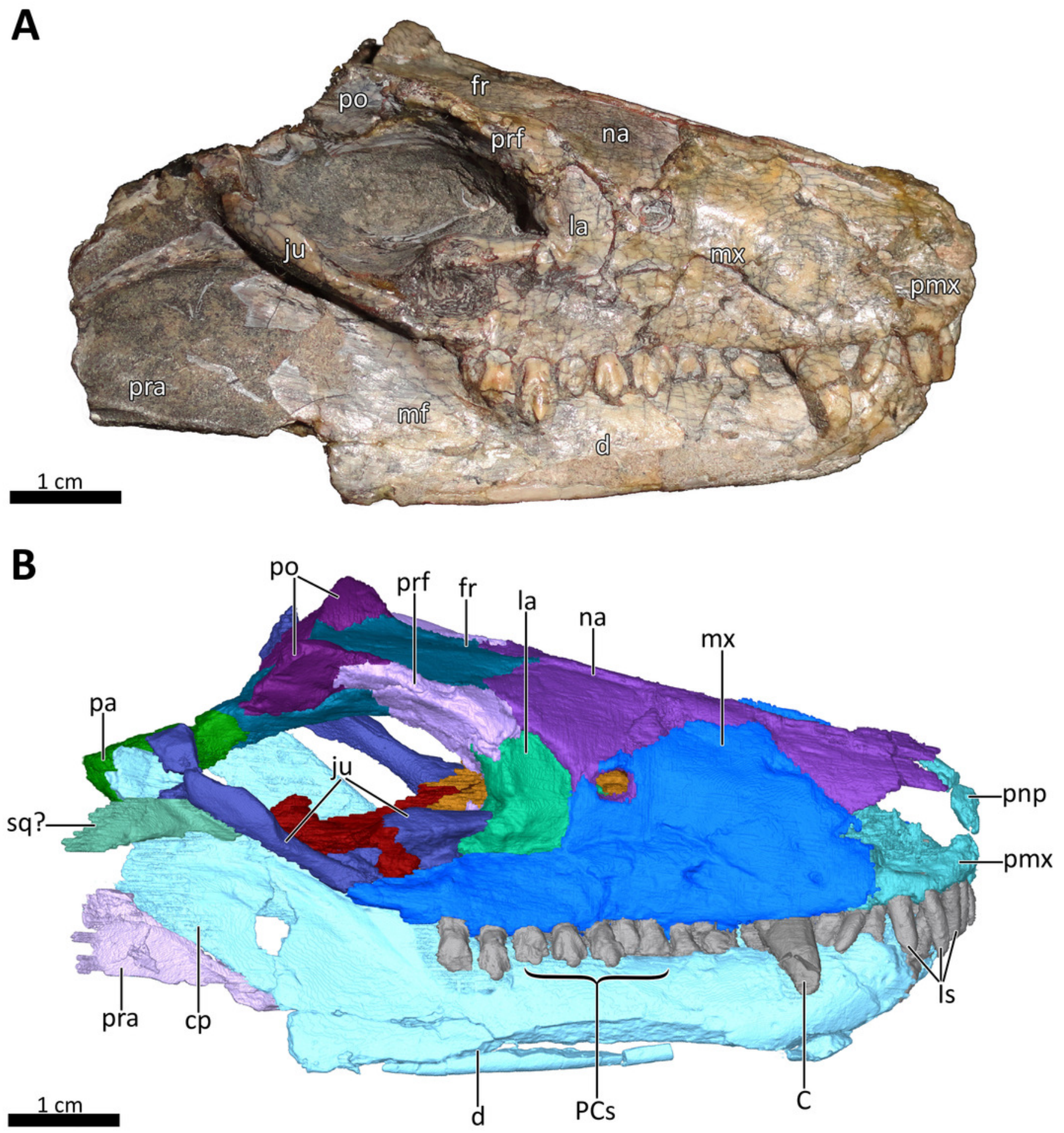




\section{Figure 3}

BSPG 1934-VIII-7 in left lateral view.

(A) Photograph and (B) 3D reconstruction of the specimen. Abbreviations: $\mathrm{C}$, upper canine;

$\mathrm{cp}$, coronoid process; d, dentary; fr, frontal; Is, upper incisors; ju, jugal; la, lacrimal; mx, maxilla; na, nasal; pa, parietal; PCs, upper postcanines; pmx, premaxilla; pnp, prenasal process of the premaxilla; po, postorbital; pra, prearticular; prf, prefrontal. Photograph in (A) by Christian F. Kammerer. Image of the 3D reconstructed skull in (B) by Luisa C. Pusch. 


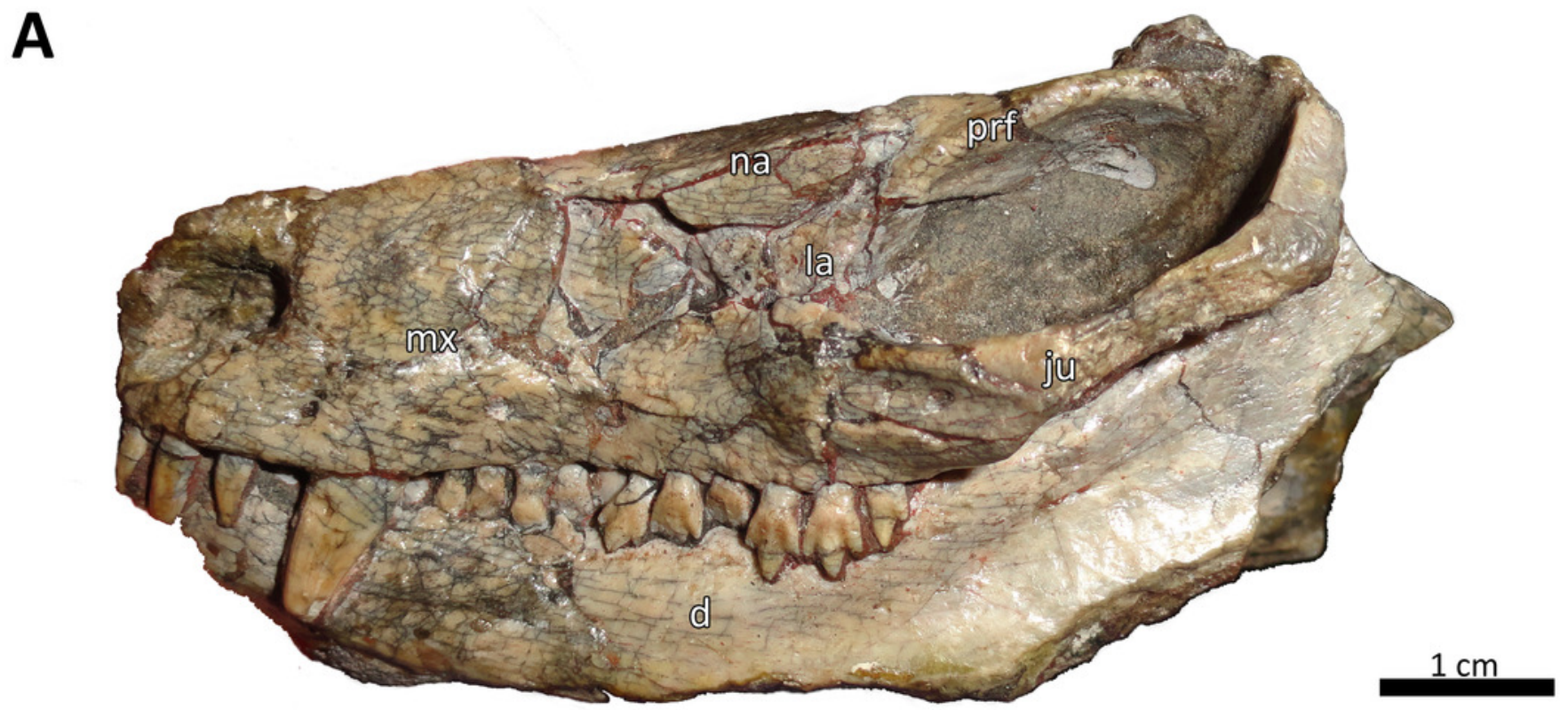

B

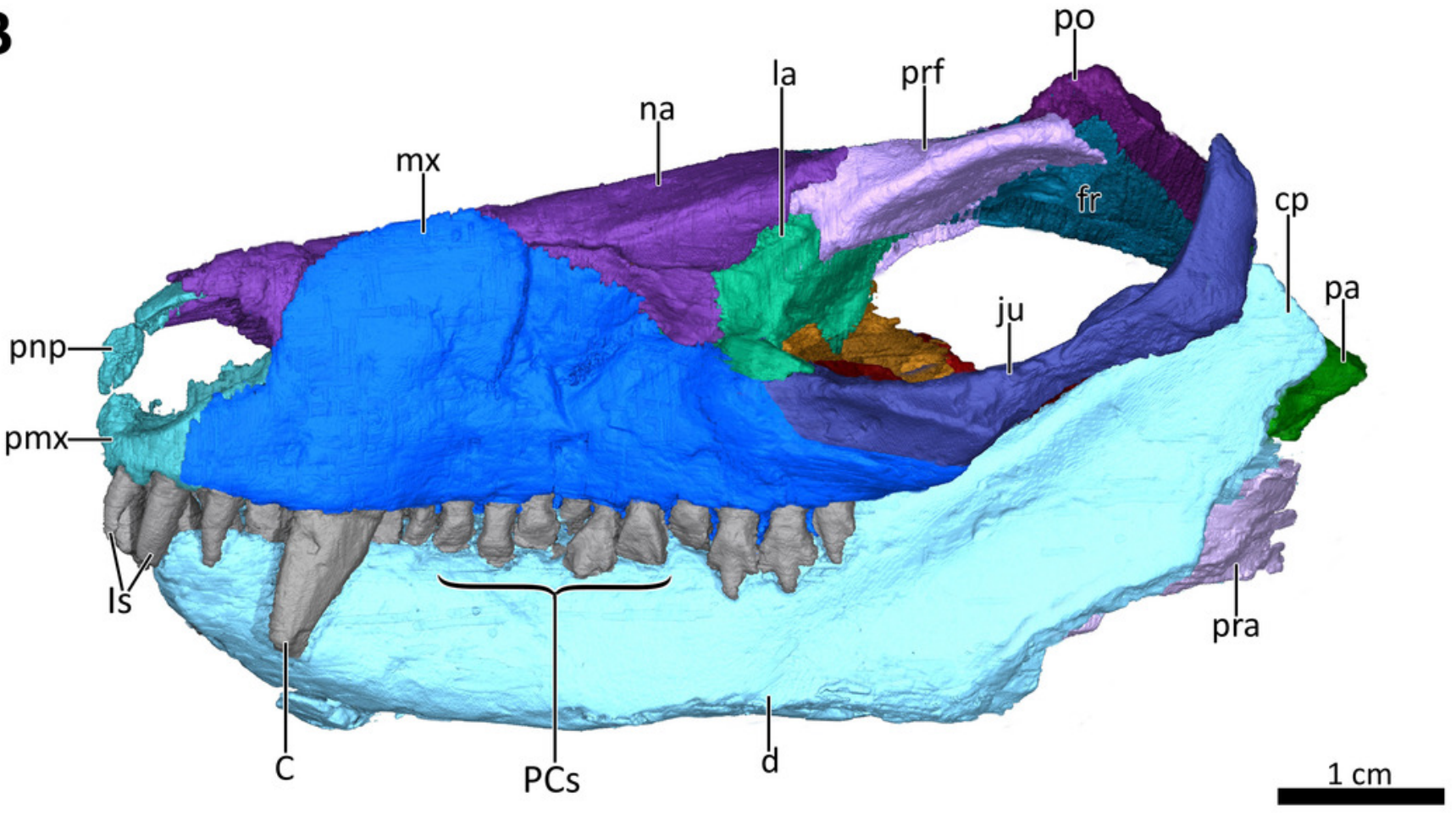




\section{Figure 4}

Mid sagittal section through the reconstructed skull and lower jaw of BSPG 1934-VIII-7, with the vomer and palatine digitally removed to show the internal morphology.

Abbreviations: cp, coronoid process; c, lower canine; d, dentary; fr, frontal; I, upper incisor; i, lower incisor; ju, jugal; la, lacrimal; mx, maxilla; na, nasal; obl, olfactory bulb location; och, olfactory chamber; olac, opening of lacrimal canal; pa, parietal; pcs, lower postcanines; pmx, premaxilla; pnp, prenasal process of the premaxilla; po, postorbital; pra, prearticular; prf, prefrontal; pt, pterygoid; rch, respiratory chamber; rmxt?, ridge for cartilaginous maxilloturbinals?; sp, splenial; sq?, squamosal?, tf, transverse flange of the pterygoid. Image by Luisa C. Pusch

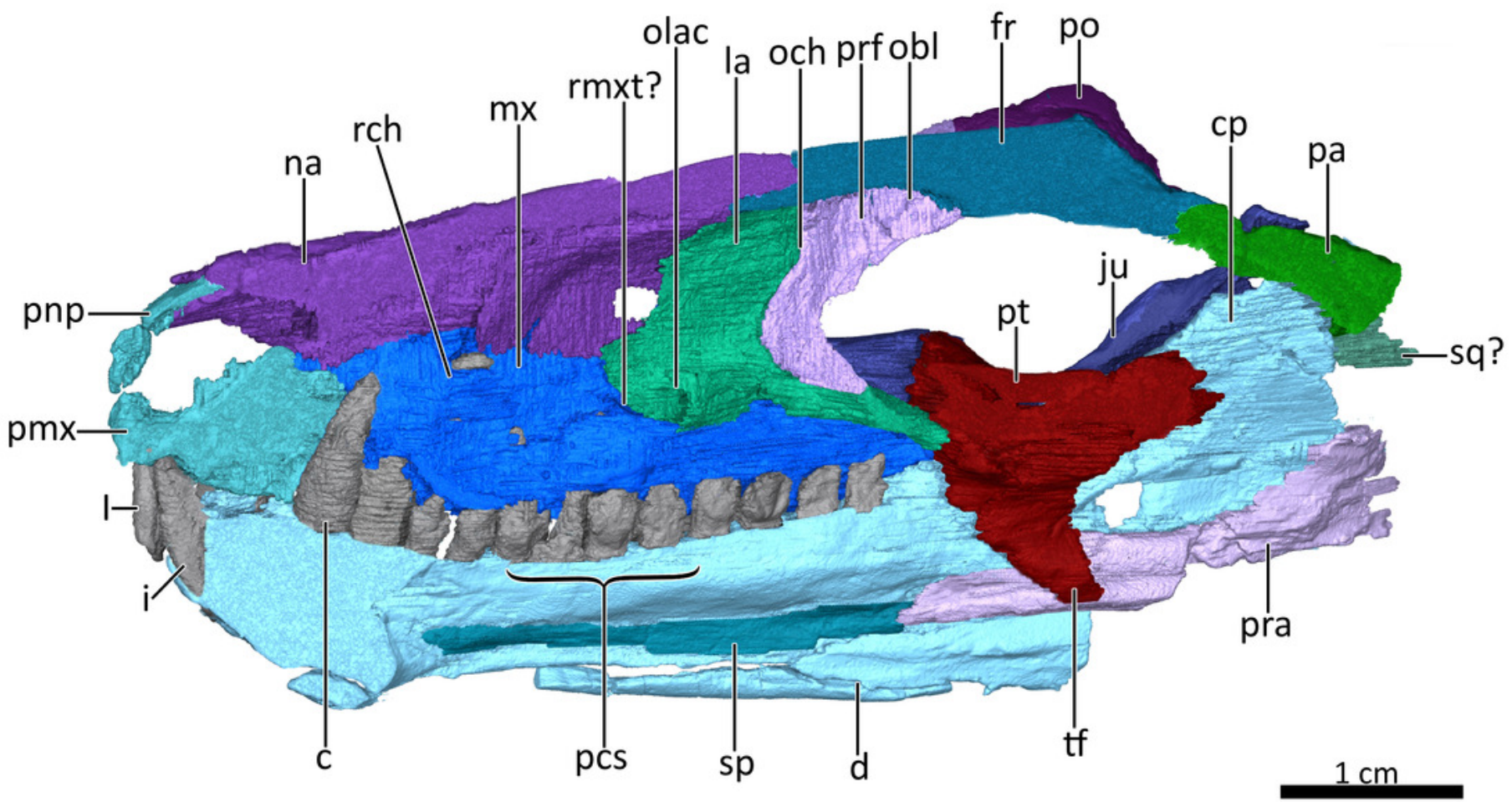




\section{Figure 5}

Transverse CT sections through the olfactory chamber (A, B) of BSPG 1934-VIII-7.

Abbreviations: d, dentary; fr, frontal; ju, jugal; la, lacrimal; lac, lacrimal canal; Ir, lateral ridge; $\mathrm{mr}$, median ridge; $\mathrm{mx}$, maxilla; na, nasal; $\mathrm{np}$, nasopharyngeal passage; och, olfactory chamber; olac, opening of lacrimal canal; PC, upper postcanine; pc, lower postcanine; pl, palatine; prf, prefrontal; pt, pterygoid; $t$, transverse lamina; vo, vomer. CT images in (A) and (B) by Luisa C. Pusch.
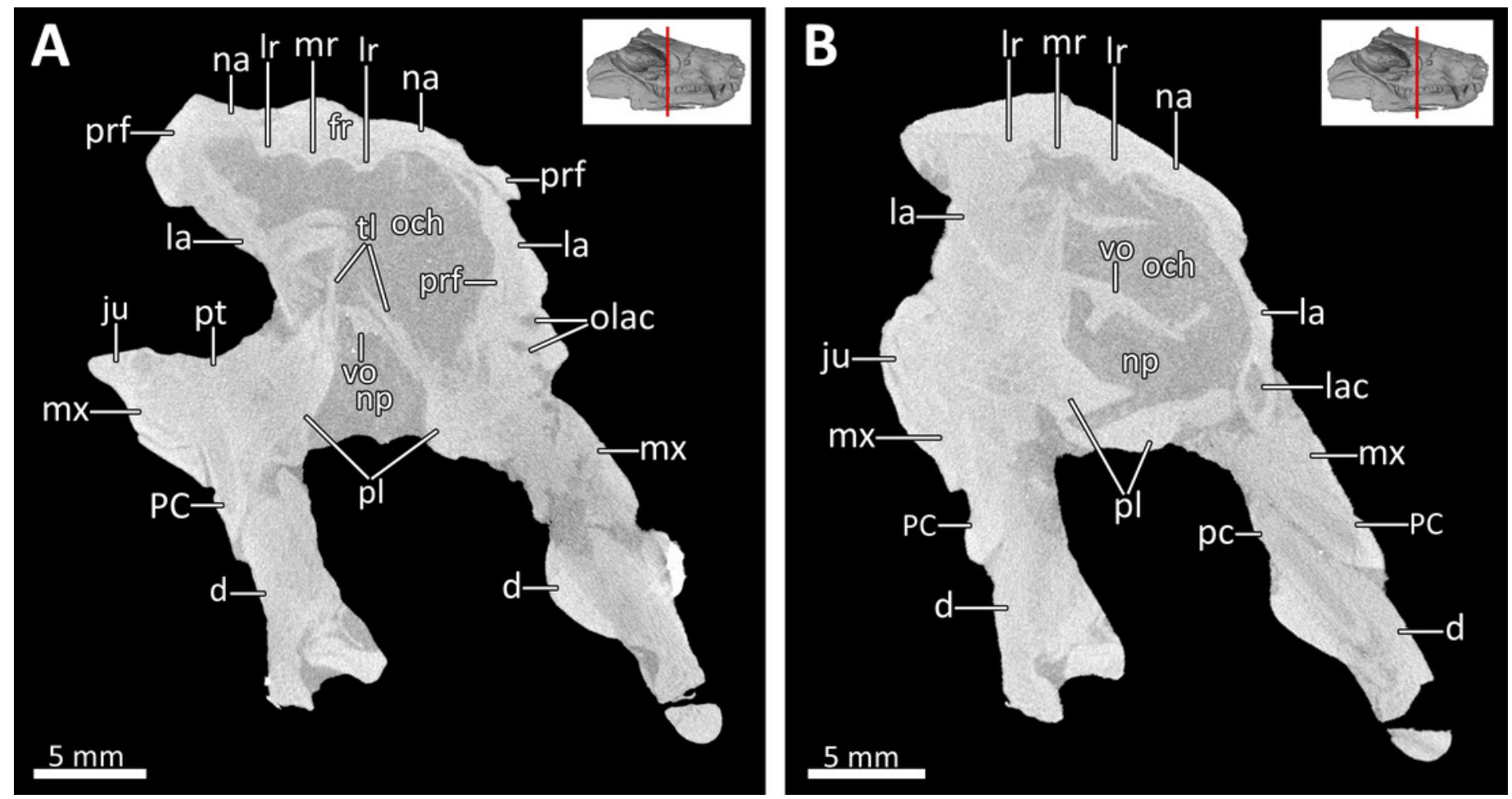


\section{Figure 6}

3D reconstruction of the skull roof in ventrolateral view.

Asterisk marks the location of the olfactory bulbs of the brain on the ventral surface of the frontals. Abbreviations: fr, frontal; na, nasal; pa, parietal; po, postorbital; prf, prefrontal; rnt, ridge for cartilaginous nasal turbinals. Image by Luisa C. Pusch.

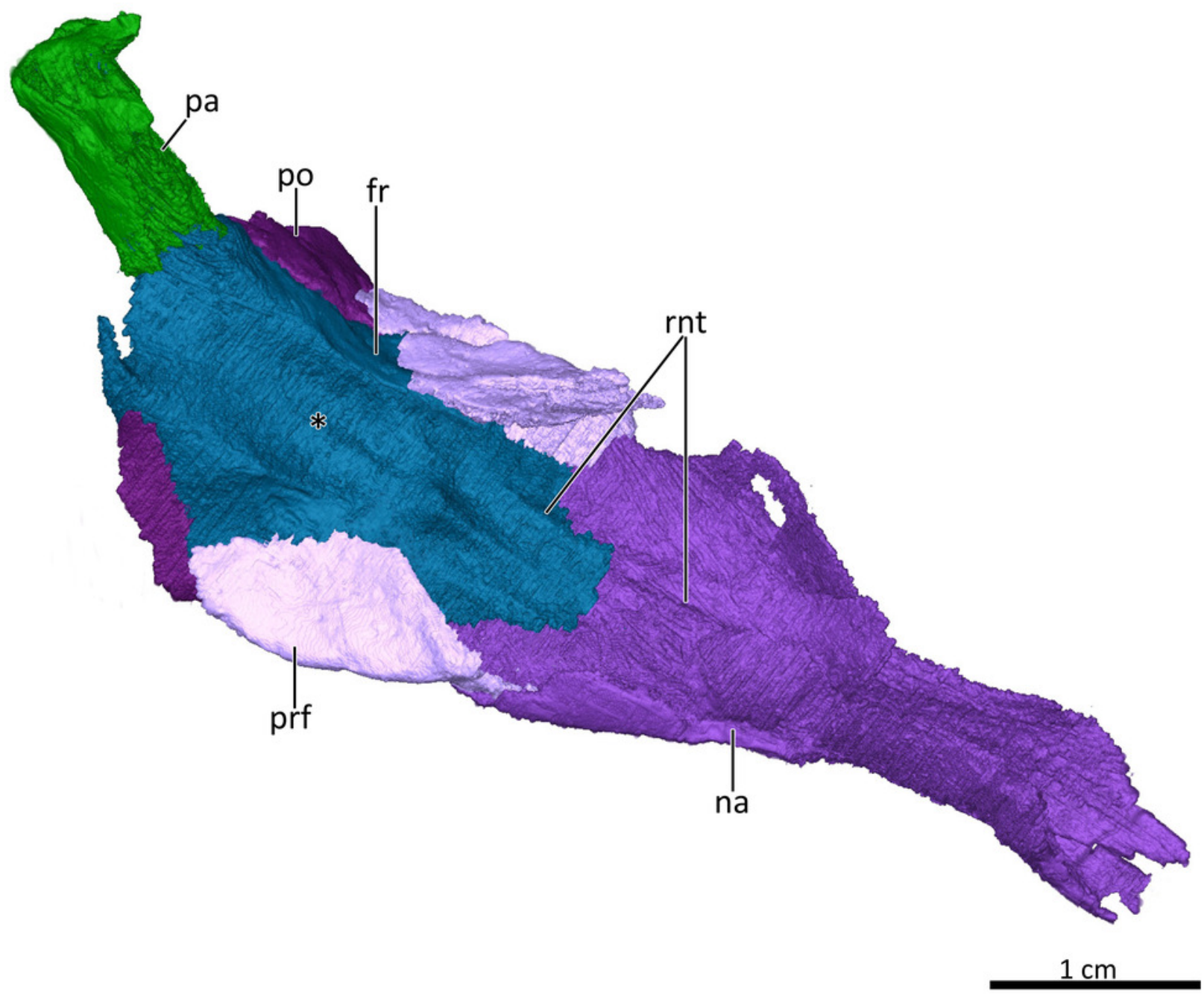




\section{Figure 7}

3D reconstruction of the snout of BSPG 1934-VIII-7.

(A) Snout in dorsal aspect with the nasals, lacrimals, prefrontals, postorbitals, frontals, parietal and squamosal digitally removed to expose its internal structure. (B) Ventral view of the palate. Abbreviations: $\mathrm{C}$, upper canine; Is, upper incisors; ju, jugal; mx, maxilla; pa, parietal; PCs, upper postcanines; pl, palatine; pmx, premaxilla; ppmx, palatal process of the maxilla; pt, pterygoid; sc, secondary choana; sq?, squamosal?; vo, vomer. Images in (A) and (B) by Luisa C. Pusch. 
A

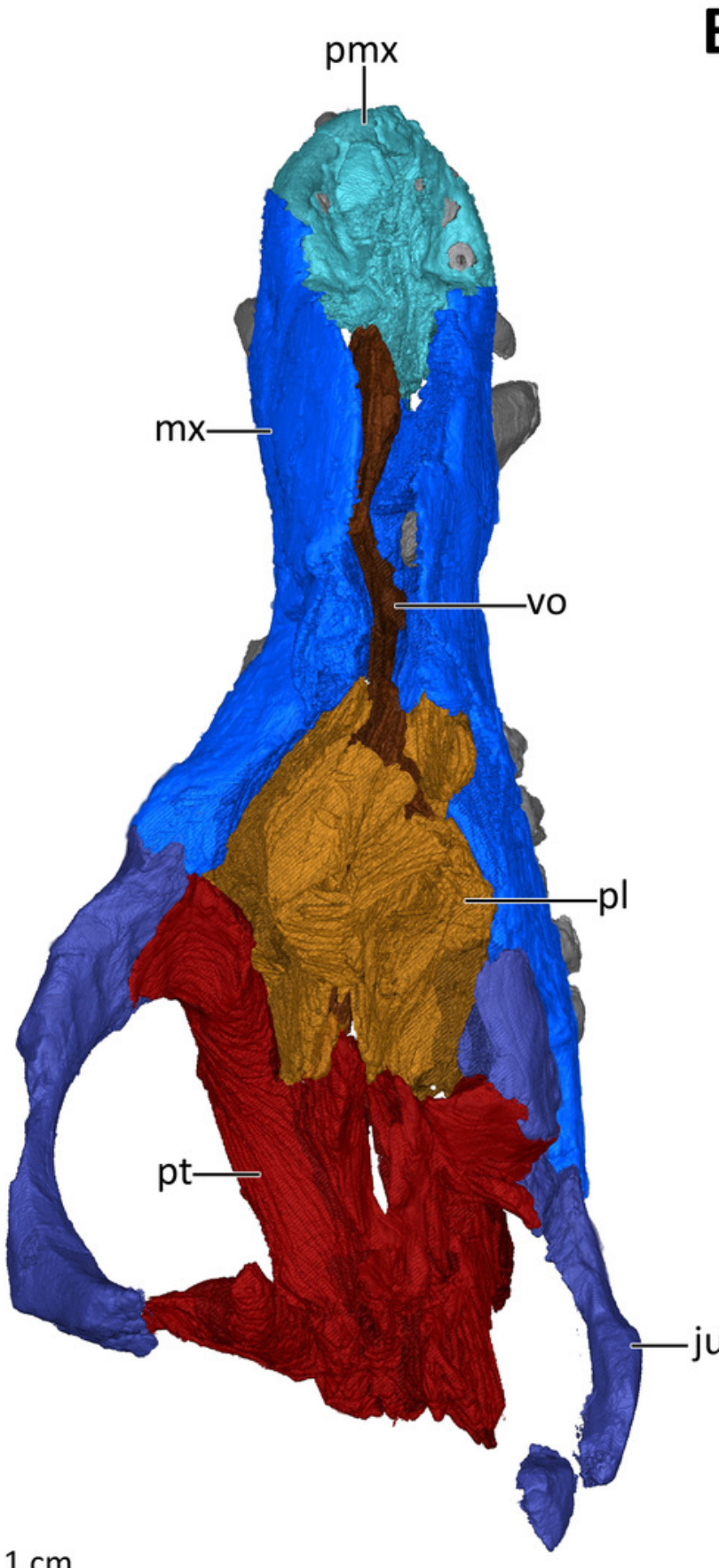

B

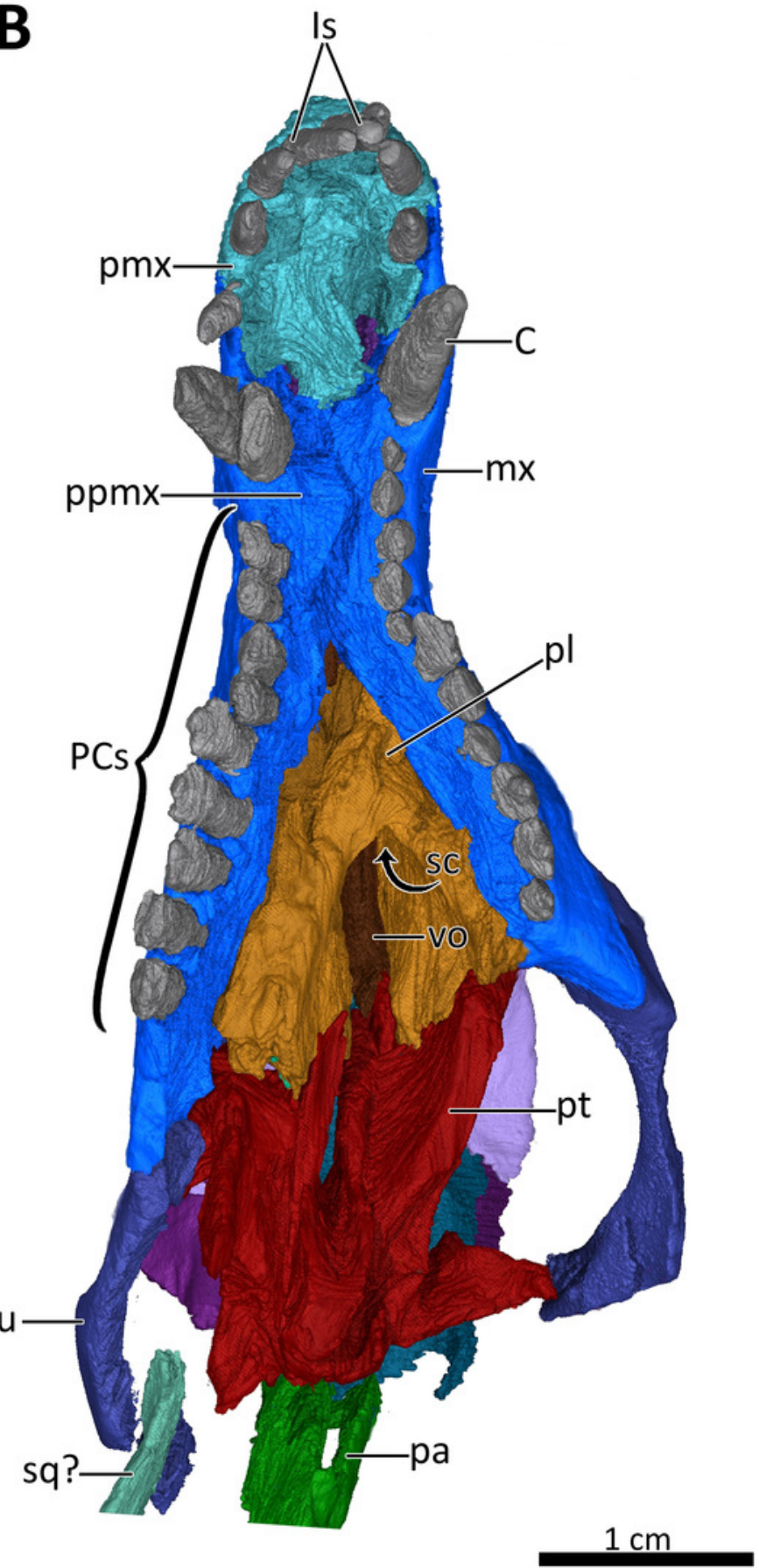


Figure 8

3D reconstruction of the lower jaw of BSPG 1934-VIII-7.

(A) right dorsolateral, (B) dorsal, and (C) ventral view of the mandible. Abbreviations: ang, angular; $c p$, coronoid process; $c s$, lower canines; $d$, dentary; is, lower incisors; pcs, lower postcanines; pra, prearticular; sp, splenial. Images in (A), (B) and (C) by Luisa C. Pusch. 
A

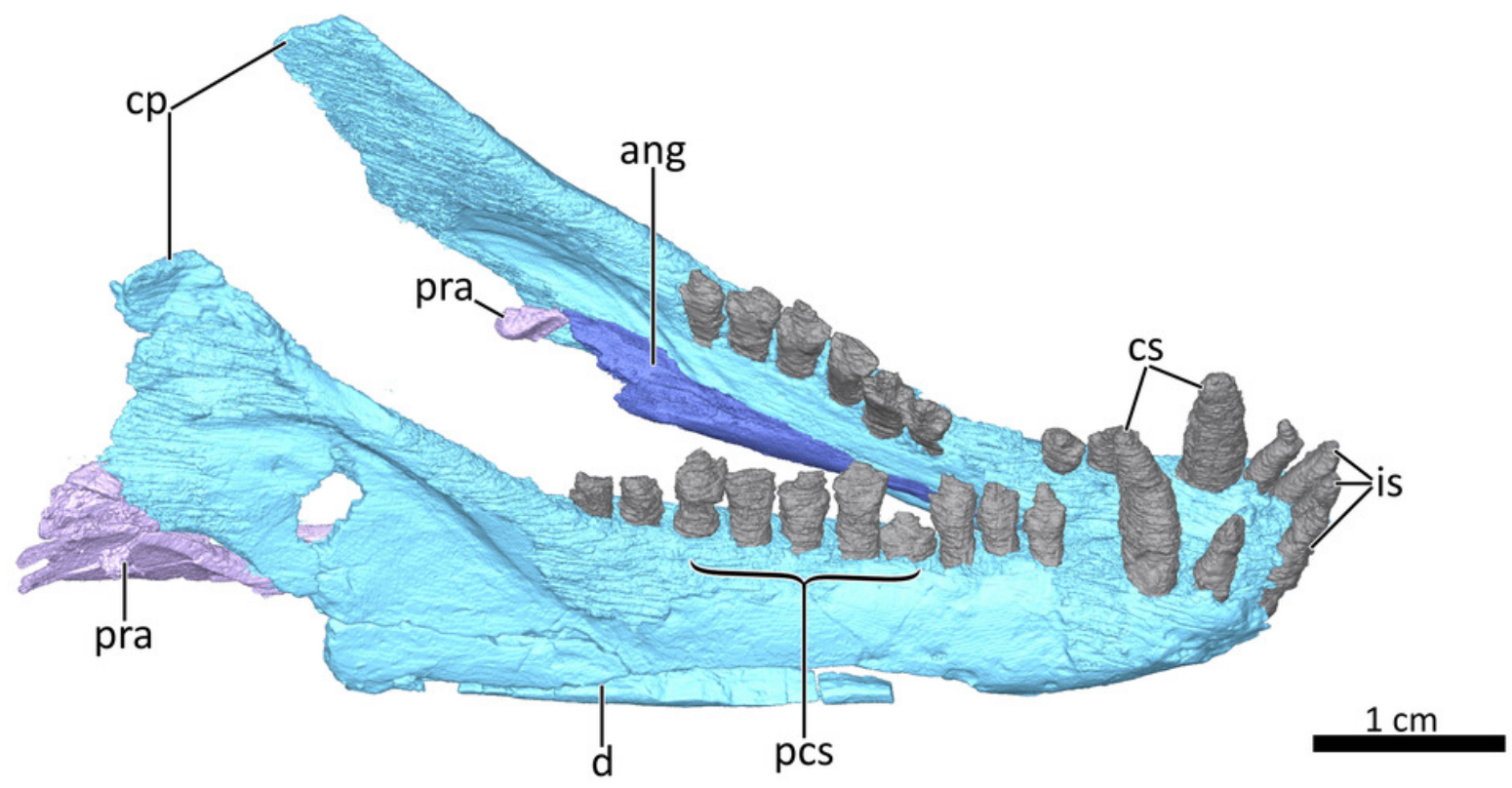

B

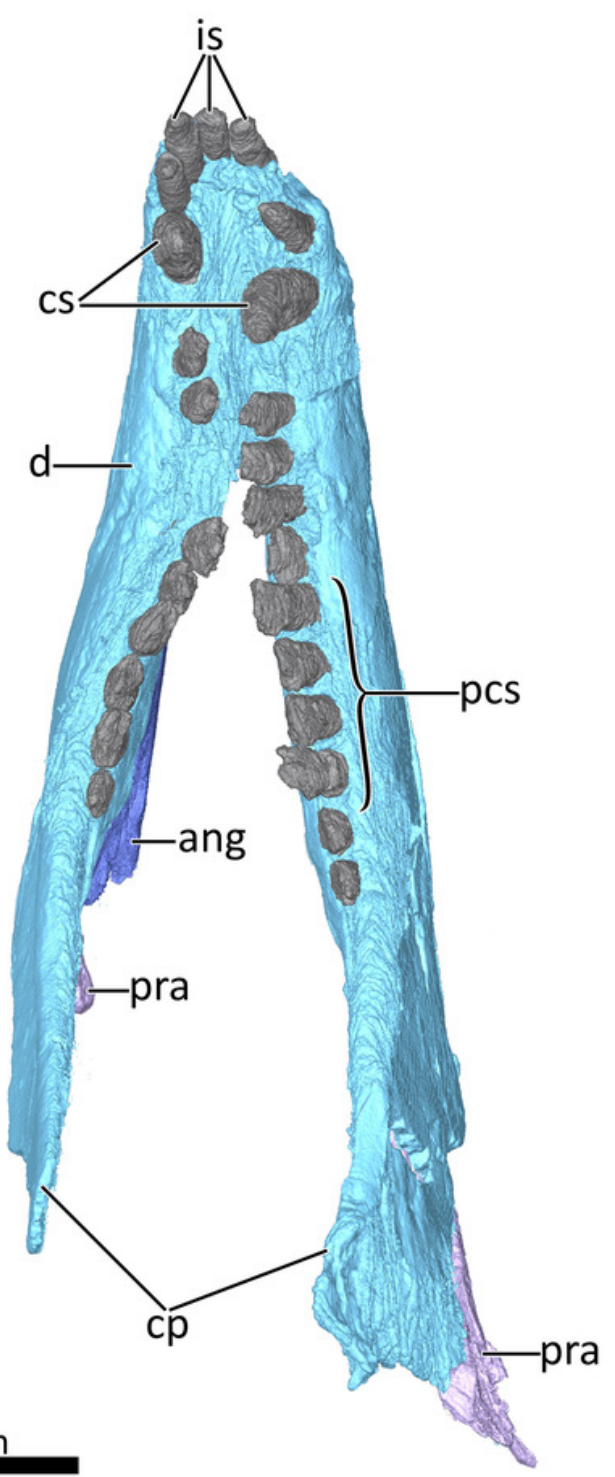

C

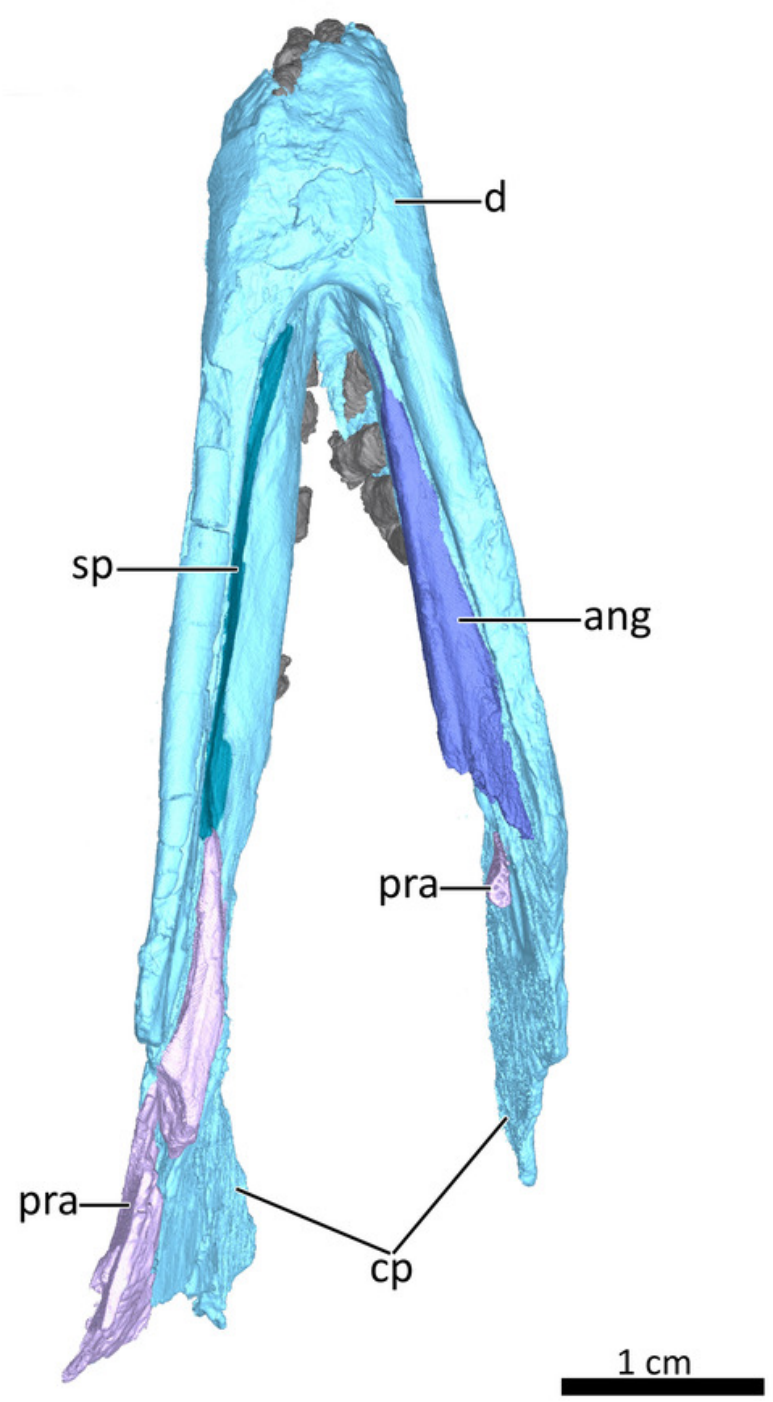


Figure 9

Symphyseal region of BSPG 1934-VIII-7.

(A) Anterior and (B) ventral views of the symphyseal region highlighted with an asterisk. (C) and (D) virtual horizontal CT sections through the symphyseal region. Abbreviations: ang, angular; d, dentary; sy, symphysis. Photograph in (A) by Luisa C. Pusch and in (B) by Christian F. Kammerer. CT images in (C) and (D) by Luisa C. Pusch. 
A

\section{$5 \mathrm{~mm}$}
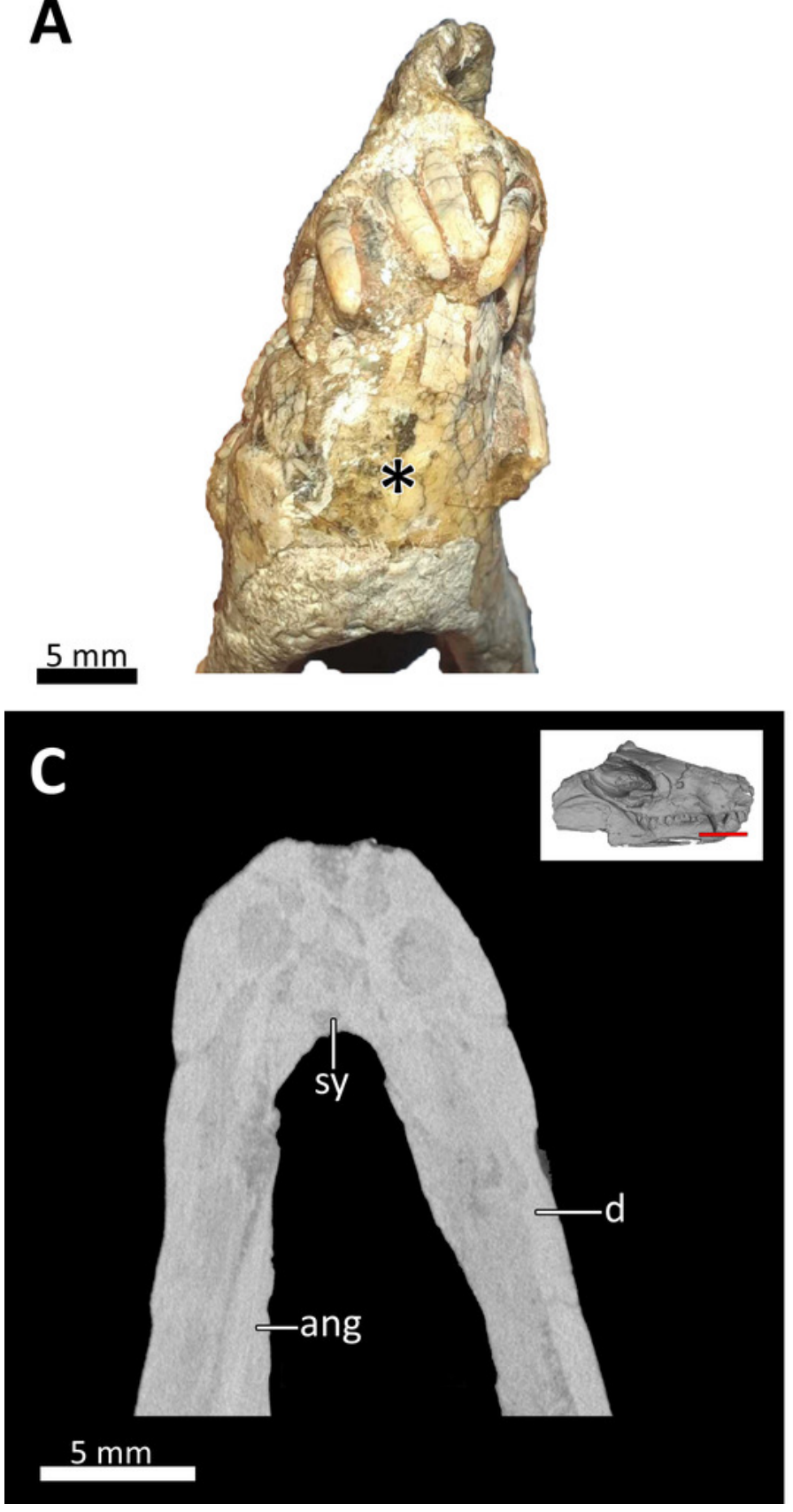

B

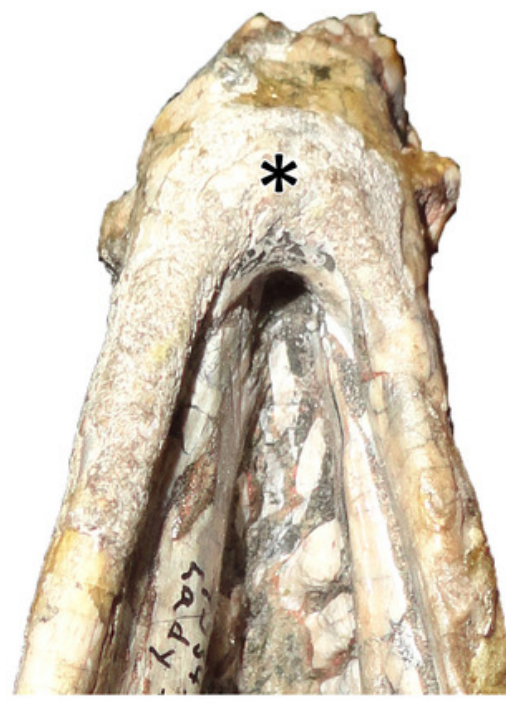

$5 \mathrm{~mm}$

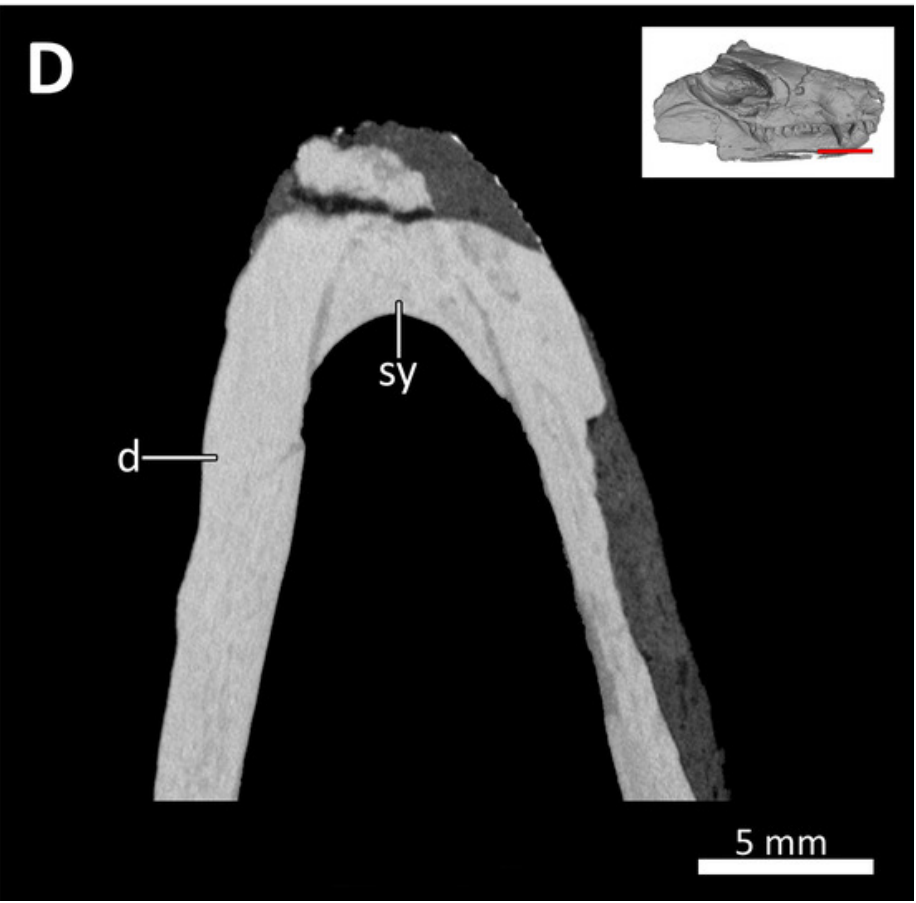




\section{Figure 10}

Maximum parsimony strict consensus (left) and Bayesian inference majority rule (right) topologies of Permo-Triassic theriodonts obtained from the phylogenetic analyses.

Nodes of clades of interest are labeled: (A) Eutheriodontia; (B) Therocephalia; (C) Cynodontia; (D) Charassognathidae; (E) Abdalodontinae; (F) Epicynodontia; (G) Eucynodontia. Numbers at nodes represent clade support, if no bootstrap value is indicated on the left it was less than $50 \%$, and Bayesian posterior probabilities on the right. Image by Luisa C. Pusch.

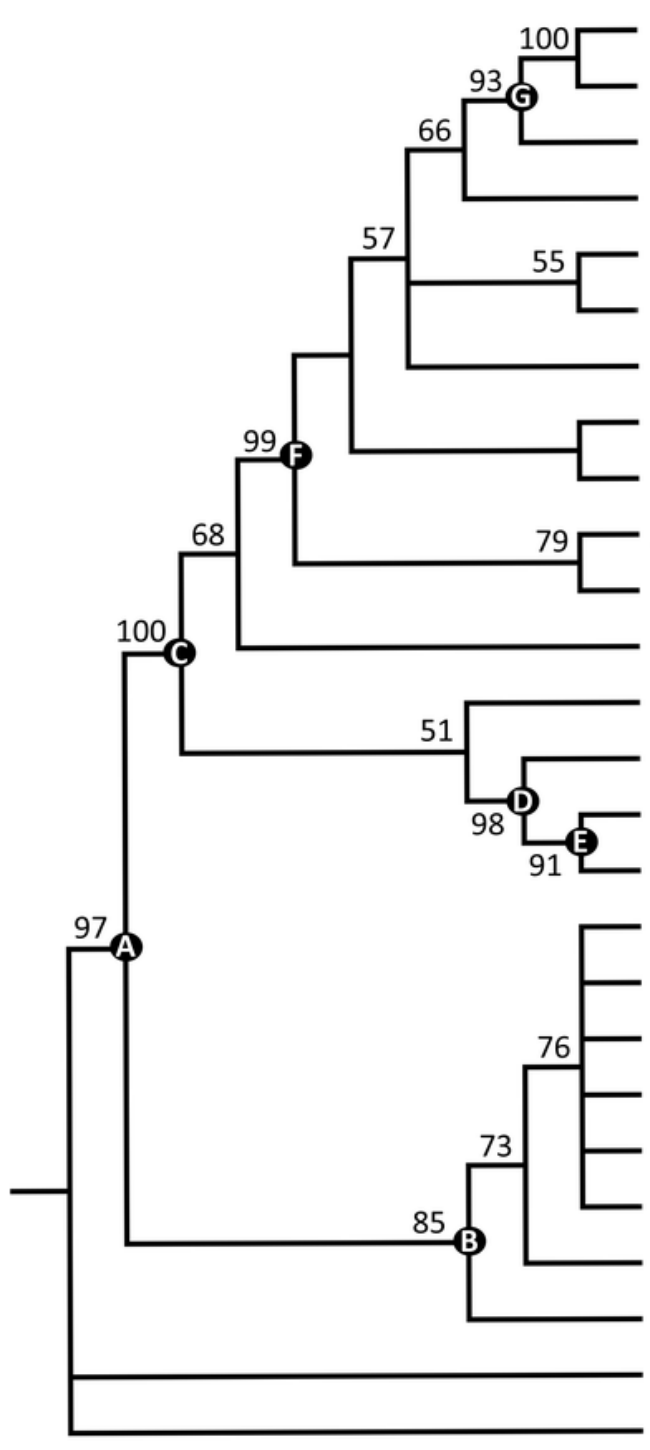

Diademodon tetragonus Cynognathus crateronotus

Lumkuia fuzzi

Bolotridon frerensis

Platycraniellus elegans

Nanictosaurus kitchingi

Thrinaxodon liorhinus

Cynosaurus suppostus

Vetusodon elikhulu

Progalesaurus lootsbergensis

Galesaurus planiceps

Procynosuchus delaharpeae

Dvinia prima

Charassognathus gracilis

Abdalodon diastematicus

Abdalodon muchingaensis

Bauria cynops

Regisaurus jacobi

Theriognathus microps

Hofmeyria atavus

Moschorhinus kitchingi

Olivierosuchus parringtoni

Glanosuchus macrops

Lycosuchus vanderrieti

Aelurognathus tigriceps

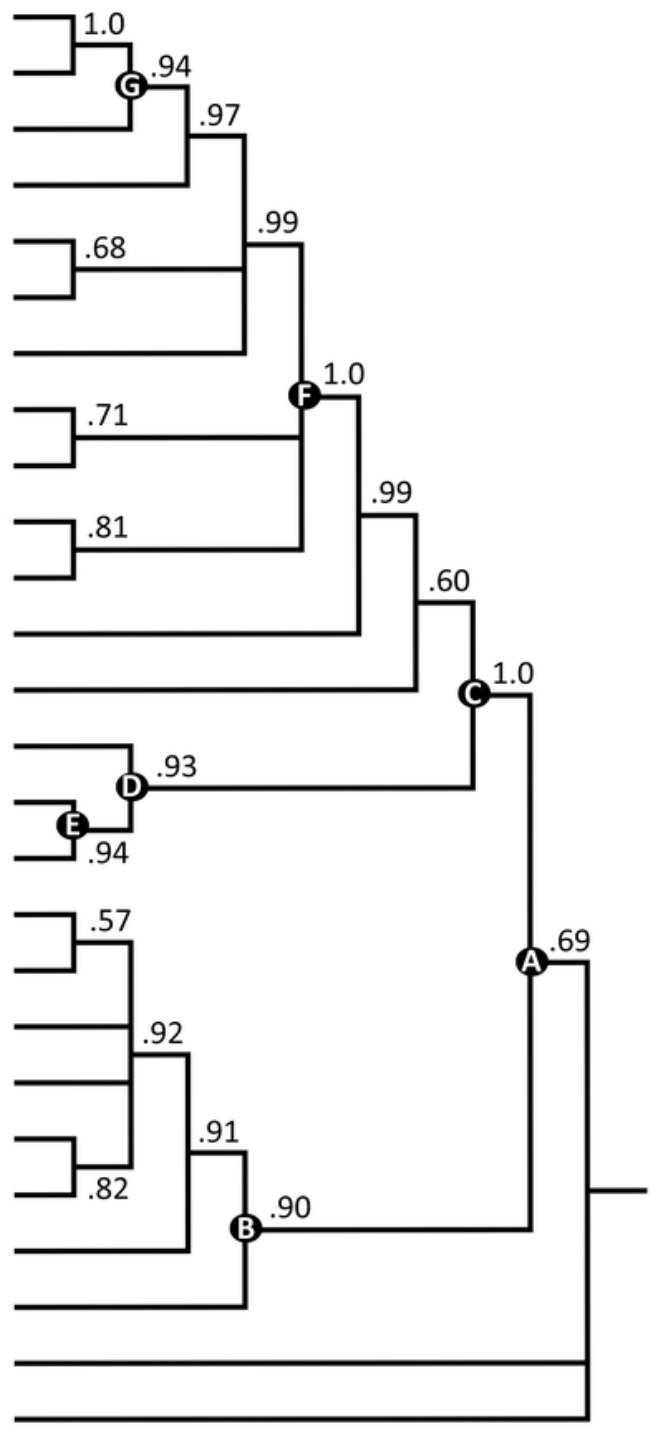

Cyonosaurus longiceps 